Geologica Macedonica, Vol. 34, No. 2, pp. 89-104 (2020)

On print ISSN $0352-1206$

On line ISSN $1857-8586$

UDC: 550.42:[551.14:669.4/.5.05(497.713)

\title{
GEOCHEMICAL PROPERTIES OF LEAD-ZINC SLAG LANDFILL FROM MHK ZLETOVO IN VELES, NORTH MACEDONIA
}

\author{
Robert Šajn ${ }^{1}$, Trajče Stafilov ${ }^{2}$, Blažo Boev ${ }^{3}$, Todor Serafimovski ${ }^{3}$, Goran Tasev $^{3}$, \\ Zlatko Ilijoski ${ }^{4}$, Ivan Boev ${ }^{3}$ \\ ${ }^{1}$ Geological Survey of Slovenia, Dimičeva ulica 14, 1000 Ljubljana, Slovenia \\ ${ }^{2}$ Institute of Chemistry, Faculty of Science, "Ss. Cyril and Methodius" University in Skopje, \\ Arhimedova 5, 1000 Skopje, North Macedonia \\ ${ }^{3}$ Faculty of Natural and Technical Sciences, Institute of Geology, "Goce Delčev" University in Štip, \\ Blvd. Goce Delčev 89, 2000 Štip, Republic of Macedonia \\ ${ }^{4}$ Civil Engineering Institute "Macedonia”, Drezdenska 52, 1000 Skopje, North Macedonia \\ Robert.Sajn@geo-zs.si
}

\begin{abstract}
A b s t r a c t: "Regional innovation scheme for zero waste extraction of critical raw materials" (RIS-RECOVER) project, was implemented within the framework of the European Institute of Innovation and Technology (EIT) to evaluate and select the most promising technologies for mineral and metallurgical extraction of elements from metallurgical slag in the Republic of North Macedonia. This project focused on metallurgical slag from the former $\mathrm{Pb}-\mathrm{Zn}$ smelting plant "MHK Zletovo", which was disposed of in the vicinity of Veles. Samples of waste material were obtained out by drilling through the slag deposit at eight locations and collecting samples at $2 \mathrm{~m}$ intervals. Using inductively coupled plasma - mass spectrometry (ICP-MS) 60 chemical elements were analyzed. It was found that the slag deposit is heterogeneous. The most abundant metals of interest for further extraction were $\mathrm{Zn}$ and $\mathrm{Pb}$, followed by $\mathrm{Cd}, \mathrm{Ag}, \mathrm{Au}$ and In. However, the following metals were also present in economical quantities: $\mathrm{As}, \mathrm{Be}, \mathrm{Bi}, \mathrm{Cu}, \mathrm{Fe}, \mathrm{Mn}, \mathrm{Nb}, \mathrm{Pd}, \mathrm{Sb}$, $\mathrm{Se}, \mathrm{Sn}, \mathrm{Te}$ and $\mathrm{Tl}$, along with rare earth elements. The average $\mathrm{Zn}$ content was $9.6 \%$ (between 5.6 and $14 \%$ ), and the total amount of about 120,000 t indicates a viable economic benefit in the recovery of metals from this landfill.
\end{abstract}

Key words: RIS-RECOVER; Pb-Zn slag deposit; MHK Zletovo; Veles; North Macedonia

\section{INTRODUCTION}

"Regional innovation scheme for zero waste extraction of critical raw materials" (RIS-RECOVER) project was implemented under the program of the European Institute of Innovation and Technology (EIT), an independent body of the European Union (Mladenovič et al., 2018). The project coordinator was the Slovenian Civil Engineering Institute (ZAG), major partners included the Geological Survey of Slovenia (GeoZS), Construction Institute from North Macedonia (GIM), "Goce Delčev" University from Štip (GDU), Montanuniversität Leoben from Austria (MUL), and Flemish Institute for Technological Research from Mol, Belgium (VITO). The project assessed mining and metallurgical waste deposits $(\mathrm{Pb}, \mathrm{Zn}, \mathrm{Cu}, \mathrm{As}, \mathrm{Sb}$, $\mathrm{Cr}, \mathrm{Ni}$ ) in the Republic of North Macedonia and to evaluate the technological and economic feasibility of extracting these metals. The larger objective of the project is to attain zero-waste approach, i.e. material remaining after extraction of metals can be used as raw material in construction industry. The study was divided into two parts: (1) collection and analysis of existing data and (2) selection of the most promising technologies for extraction and identification of non-technological barriers and opportunities.

The first part of the study produced an overview of data published in various reports from research carried to date on the following mining, processing, and metallurgical plants in the Republic of North Macedonia, including: $\mathrm{Pb}-\mathrm{Zn}$ mines "Sasa" near Makedonska Kamenica, "Toranica" near Kriva Palanka, "Zletovo" near Probištip, copper mine "Bučim" near Radoviš, "Lojane" the abundant As$\mathrm{Sb}-\mathrm{Cr}$ mine, "FENI" ferronickel smelter near Kavadarci, $\mathrm{Pb}-\mathrm{Zn}$ smelter "Zletovo" in Veles and ferrochrome smelter "Jugohrom" in Jegunovce. 
The main task was the collection of all available data on mining and flotation waste deposits in the Republic of North Macedonia. The data, which includes chemical analysis, quantities, leaching tests, geological data, extraction and processing, demand for construction materials, were systemized and published. Selection process of the most promising sites for sampling and additional chemical analyses of the samples was carried out. The potential technologies for mineral and metallurgical extraction and the availability of local resources for technological implementation were also be evaluated; however, the focus of this study was on the metallurgical slag deposit of the former "MHK Zletovo" $\mathrm{Pb}-\mathrm{Zn}$ smelting plant in Veles.

\section{STUDY AREA: PB-ZN SLAG DEPOSIT IN VELES}

The town of Veles is an urban and industrial area located in the Vardar river valley, $55 \mathrm{~km}$ south of the capital city of Skopje (Figure 1). In 2002, the municipality of Veles had 55,000 inhabitants, while the population of the town was 44,000 . Veles is the most polluted town in North Macedonia due to contamination of soil and air by the former $\mathrm{Pb}-\mathrm{Zn}$ smelter plant located in the town of Veles. The Macedonian Institute for Health Protection reported that, when the plant was operating, the capacity was $62,000 \mathrm{t}$ of zinc, 47,000 t of lead and 120,000 t of sulfuric acid in 2002 (Nikolovski, 2008). It was also reported that these emissions caused elevated concentrations of lead in blood of Veles school children (Kochubovski, 2009).

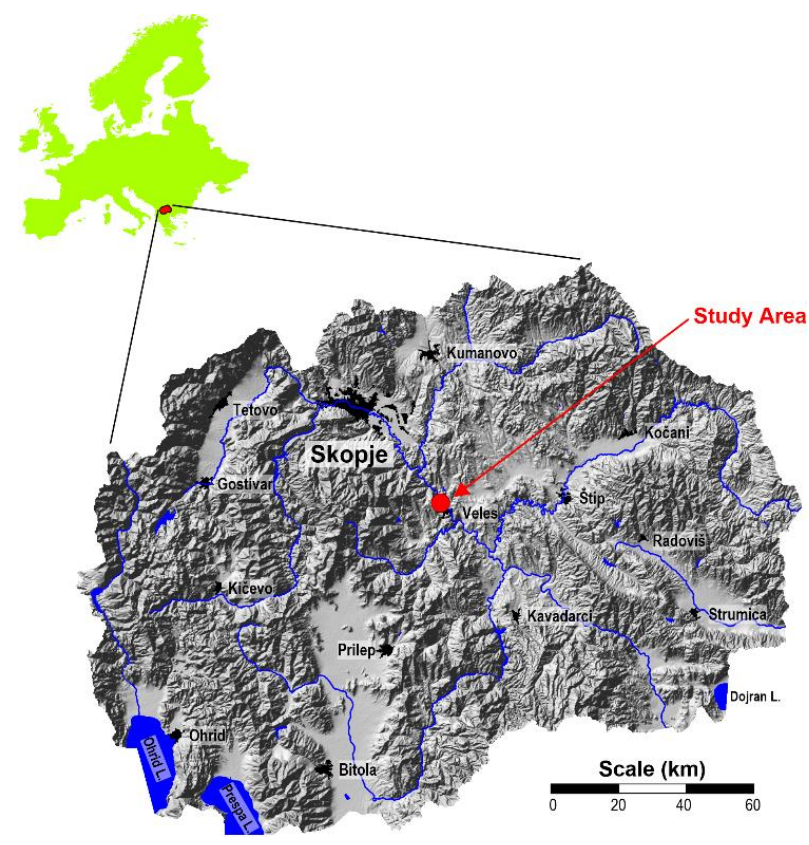

Fig. 1. Map of the Republic of North Macedonia showing the location of Veles

The smelter plant for the production of $\mathrm{Pb}$ and $\mathrm{Zn}$ from the $\mathrm{Pb}-\mathrm{Zn}$ concentrates was commissioned in 1973 and closed in 2002. During the last 15 years (1987-2002) the smelter produced about $300 \mathrm{t}$ of $\mathrm{Cd}$ and minor amounts of $\mathrm{Ag}$ and $\mathrm{Au}$. A feasibility study on MHK Zletovo (EAR-MOEPP-Eptisa, 2007), revealed that 1.8 million $t$ of slag was dumped at a site that covered a surface area of $33,000 \mathrm{~m}^{2}$. The composition of the slag was $7 \% \mathrm{Zn}, 1 \% \mathrm{~Pb}$ and 2 to $4,000 \mathrm{mg} / \mathrm{kg}$ of other potentially toxic elements (PTE), including $\mathrm{Mn}, \mathrm{Cu}, \mathrm{Ni}$ and As. The slag was only partially covered and dust emissions were obvious. It was assumed that the Vardar river was also affected by this dump.

Due to the high content of PTEs ( $\mathrm{Pb}, \mathrm{Zn}$ and $\mathrm{Cd}$ ) in dust emissions from the plant and slag deposit, it was expected that the surrounding soil would also be contaminated with these elements. Research on soil contamination by various elements has been conducted (Stafilov et al., 2008, 2010, 2016; Pančevski, 2006, 2015; Jeftimova et al., 2016) and found very high the content of anthropogenic elements, such as $\mathrm{Au}, \mathrm{Cd}, \mathrm{Cu}, \mathrm{Hg}, \mathrm{In}, \mathrm{Pb}, \mathrm{Sb}$, $\mathrm{Se}$ and $\mathrm{Zn}$, in soil samples collected around the smelter and adjacent parts of town. The content of elements in the topsoil compared to European topsoil (Salminen et al., 2005) is higher from 2.2-fold for $\mathrm{Sb}$ to 27 -fold for $\mathrm{Cd}$. The highest content of PTEs in the contaminated area was $600 \mathrm{mg} / \mathrm{kg}$ for $\mathrm{Cd}, 1.5 \%$ for $\mathrm{Pb}$ and $2.7 \%$ for $\mathrm{Zn}$. These values are considered very high. In the soil from the industrial area the average content of $\mathrm{Cd}$ exceeded the mean values for $\mathrm{Cd}$ in Europe by more than 110 times.

The spatial distribution of individual elements did not differ significantly. In the topsoil, a clear anomaly was visible around the $\mathrm{Pb}-\mathrm{Zn}$ smelter in Veles and the adjacent urban area. The shape of the propagation halo was strongly influenced by local wind and the shape of the river basin. Contamination by $\mathrm{As}, \mathrm{Cu}$ and $\mathrm{Hg}$ was significant. According to Stafilov et al. (2010), an area of critically polluted topsoil was identified as containing $6.6 \mathrm{~km}^{2}$ of $\mathrm{Cd}$, $4.2 \mathrm{~km}^{2}$ of $\mathrm{Pb}$ and $3.8 \mathrm{~km}^{2}$ of $\mathrm{Zn}$. The content of the six chemical elements ( $\mathrm{As}, \mathrm{Cd}, \mathrm{Cu}, \mathrm{Hg}, \mathrm{Pb}$ and $\mathrm{Zn}$ ) exceeded the critical value of $6.8 \mathrm{~km}^{2}$. The critically-polluted area has an elliptical shape, which is a consequence of the wind rose. 
Based on the assumption that the critically contaminated zone could be larger than already defined area, additional investigations were performed concentrated on the area to the northwest to characterize the area of contamination (Pančevski, 2006, 2015; Stafilov, 2019). An additional 75 samples were collected in the northern and northwestern parts of the Veles region covering a total area of 100 $\mathrm{km}^{2}$. The results indicate that soil contaminated with $\mathrm{As}, \mathrm{Cd}, \mathrm{Cu}, \mathrm{Pb}, \mathrm{Sb}$ and $\mathrm{Zn}$ exceeded the target values in the area of $70 \mathrm{~km}^{2}$, while the area with soil contaminated above the intervention values was 14 $\mathrm{km}^{2}$.

Air pollution by particles containing high levels of PTEs in Veles and its surroundings was first determined by a moss biomonitoring study carried out in 2002 (Barandovski et al., 2008). Due to soil contamination and dust emissions from the slag, high levels of $\mathrm{Cd}, \mathrm{Pb}, \mathrm{Zn}$ and other PTEs were present in the air in follow-up studies, conducted every five years (Barandovski et al., 2012, 2013, 2015, 2020; Stafilov et al., 2018). Air pollution in the town of Veles was also monitored using dust samples from 33 houses, 27 of which came from homes in the town of Veles, 3 from the nearby village of Bašino Selo and 3 from villages southwest of Veles (Pančevski, 2006; Stafilov, 2019). The content of
$\mathrm{Cd}, \mathrm{Pb}$ and $\mathrm{Zn}$ in dust samples from the houses was very high, with an average content of $240 \mathrm{mg} / \mathrm{kg}$ of $\mathrm{Cd}$ in attic dust and $19 \mathrm{mg} / \mathrm{kg}$ in house dust samples. A very high $\mathrm{Pb}$ content was found in both attic dust (6300 mg/kg) and household dust (460 mg/kg).

Apart from the air pollution, pollution of the water and sediment of the Vardar river was also found (Serafimovski et al., 2013; Ilić Popov et al., 2014, 2016). A study of the level of contamination (especially by $\mathrm{Cd}, \mathrm{Pb}$ and $\mathrm{Zn}$ ) in various vegetables (lettuce, carrot, green garlic and green onion) grown in contaminated soil (Pančevski et al., 2014a, 2014b, 2016) confirmed that the content of PTEs in agricultural soils correlates with high levels of $\mathrm{Pb}$, $\mathrm{Zn}$ and $\mathrm{Cd}$ in agricultural food products. The average value for $\mathrm{Cd}(0.32 \mathrm{mg} / \mathrm{kg})$ was 3.2 times higher than the permissible values in fresh vegetables $(0.10$ $\mathrm{mg} / \mathrm{kg}$ ) in the Republic of North Macedonia, while the $\mathrm{Pb}$ content was 1.6-10 times higher than the its permissible value.

Of all the earlier studies, the RIS-RECOVER project was focused on the metallurgical slag from the former $\mathrm{Pb}-\mathrm{Zn}$ smelter "MHK Zletovo" near Veles. Samples of the slag were collected by drilling through the slag deposit at seven locations at $2 \mathrm{~m}$ interval.

\section{MATERIALS AND METHODS}

\section{Vertical air-core drilling in Pb-Zn slag deposit}

The field work was carried out in July 2018. A deep air core drilling program was designed to collect samples from the $\mathrm{Pb}-\mathrm{Zn}$ metallurgical waste dump at Veles (Figures 2 and 3). This task was performed by experts from three institutions: GeoZS,
GIM and GDU. A suitable drilling method was based on physical and mechanical properties of the slag deposit. Therefore, for the slag deposit in Veles the following two drilling methods were applied:

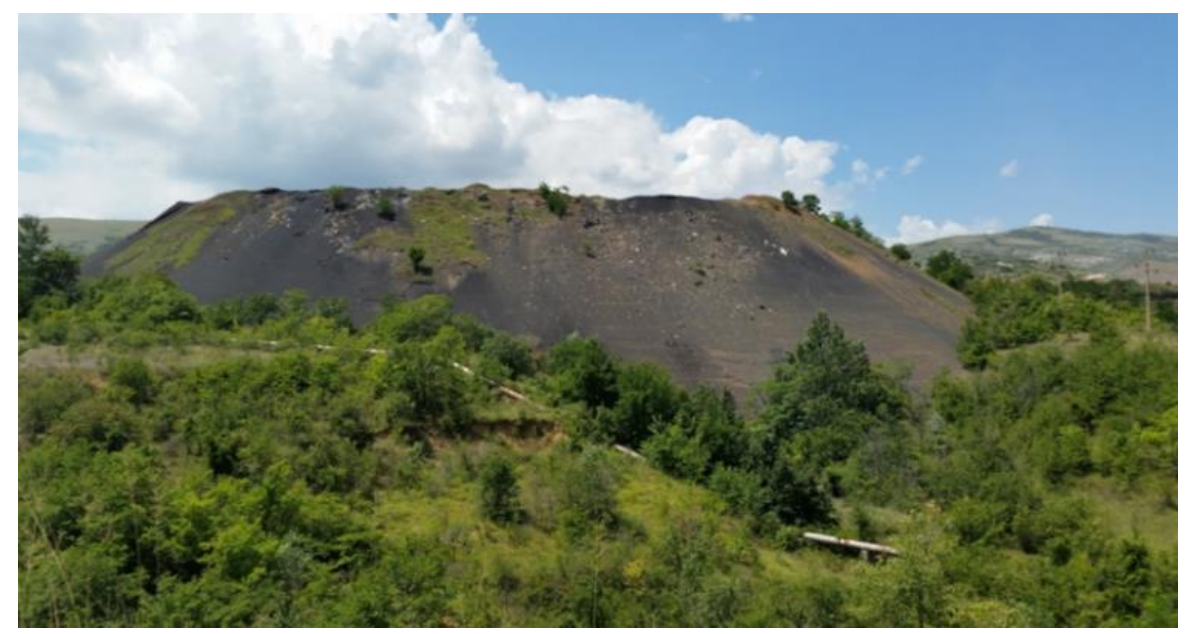

Fig. 2. Veles slag deposit (photo R. Šajn) 


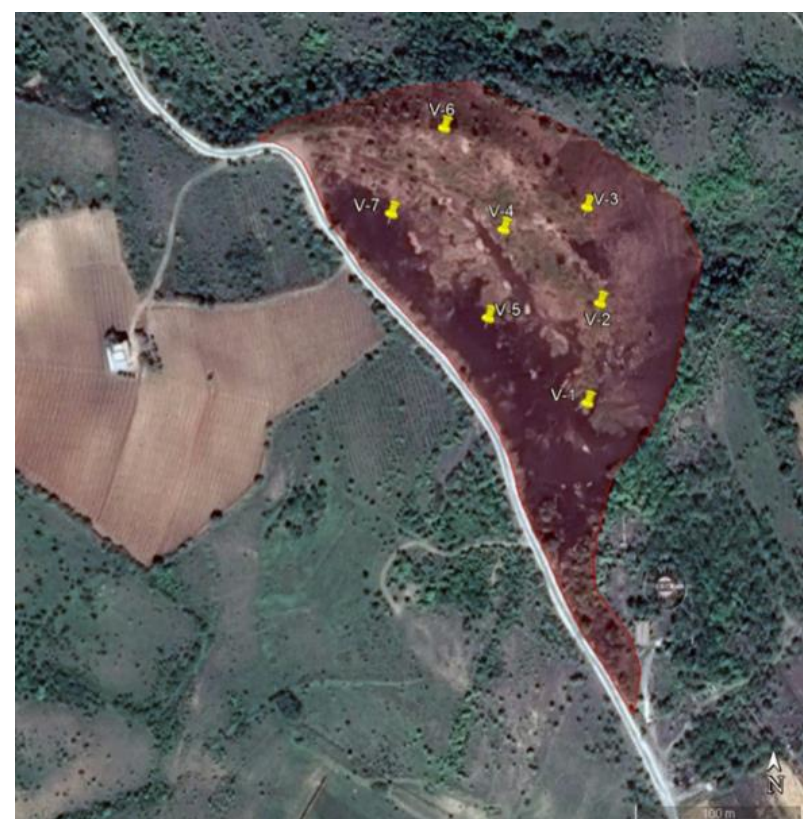

Fig. 3. Locations of the seventh air core drillings

Drilling by core drilling without drilling fluid. Single core tubes were used in this method of rotary drilling because this method guarantees $100 \%$ core recovery. The drilling speed was relatively slow and encountered problems at depth. The extracted core was preserved, and the presence of ground water was easily detected, and the material retained its natural moisture.

Drilling without core drilling. A rotary drilling uses air, instead of mud as a circulation material. This method does not use core tubes; instead, dril- ling is carried out with a DTH hammer (Figure 4). In terms of drilling speed, this method is considered fast drilling because the drilling material is extracted using pressurized air to retrieve the slag samples which were collected at a predetermined sampling interval of $2 \mathrm{~m}$ per sample and placed in plastic bags. The material was described visually (fractionation, colour, presence of water, etc.) and particle size distribution was reported.

The samples were collected from eight drill holes with depths between $18 \mathrm{~m}$ and $38 \mathrm{~m}$ and a total depth of approximately $230 \mathrm{~m}$. One hole (V-8) was drilled to calculate the specific gravity. For this purpose, a BEREETTA T57 drill set GEO, two rotary heads (parallel drilling and coating) with continuous coating and ATLAS COPCO XRHS 396 compressor with a capacity of $24 \mathrm{~m}^{3} / \mathrm{min}$ and a pressure of 25 bar.

The total depth of the seven holes drilled to collect samples of slag was $196 \mathrm{~m}$, of which the first $168 \mathrm{~m}$ was slag; bellow that depth, bedrock was encountered. The exact locations of the drill holes were marked using Google Earth Map (Figure 3, Table 1). A composite sample represents material from a drilling depth of $2 \mathrm{~m}$. The total number of composite samples was 97 , of which 82 samples were only metallurgical slag. The remainder of the samples contained a mixture of metallurgical waste material and host rock. A large composite sample (approximately $250 \mathrm{~kg}$ ) was collected from these samples for further laboratory analysis, which was carried out at MUL.
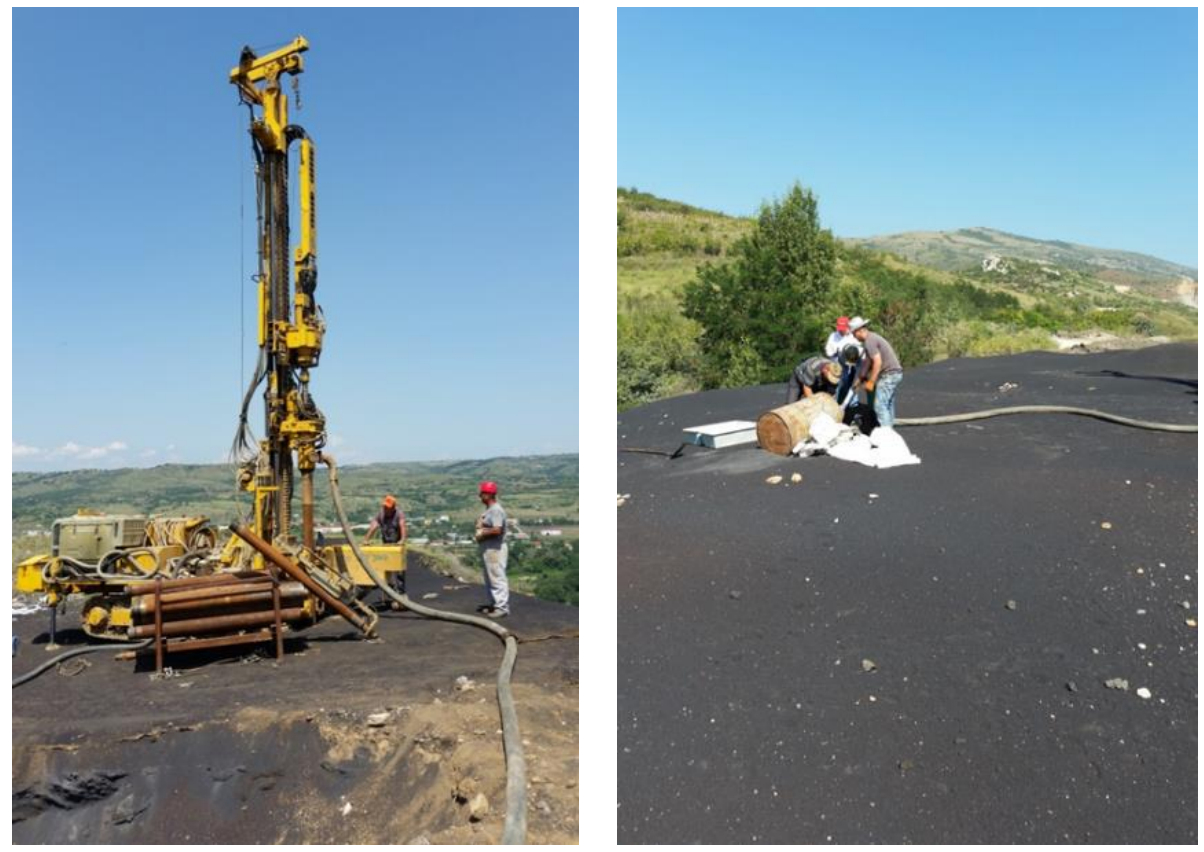

Fig. 4. Air core drilling rigs and in situ sampling method (photo R. Šajn) 
Table 1

Details of sampling locations and boreholes

\begin{tabular}{|c|c|c|c|c|c|c|}
\hline \multirow{2}{*}{$\begin{array}{l}\text { Drilling } \\
\text { site }\end{array}$} & \multirow{2}{*}{ World Geodetic System (WGS) } & \multicolumn{3}{|c|}{ Local coordinate system } & \multirow{2}{*}{$\begin{array}{l}\text { Total depth } \\
\text { (m) }\end{array}$} & \multirow{2}{*}{$\begin{array}{l}\text { Depth of landfill } \\
\qquad(\mathrm{m})\end{array}$} \\
\hline & & Easting & Northing & Elevation (m asl) & & \\
\hline $\mathrm{V} 1$ & $41^{\circ} 44^{\prime} 07.28^{\prime \prime} \mathrm{N} ; 1^{\circ} 45^{\prime} 20.98^{\prime \prime} \mathrm{E}$ & 563316.4 & 4621549.9 & 245.5 & 26 & 24 \\
\hline $\mathrm{V} 2$ & $41^{\circ} 44^{\prime} 09.01^{\prime \prime} \mathrm{N} ; 21^{\circ} 45^{\prime} 21.20^{\prime \prime} \mathrm{E}$ & 563320.9 & 4621603.6 & 245.4 & 38 & 35 \\
\hline V3 & $41^{\circ} 44^{\prime} 10.74^{\prime \prime} \mathrm{N} ; 21^{\circ} 45^{\prime} 21.04^{\prime \prime} \mathrm{E}$ & 563316.9 & 4621656.9 & 243.9 & 34 & 31 \\
\hline V4 & $41^{\circ} 44^{\prime} 10.26^{\prime \prime} \mathrm{N} ; 21^{\circ} 45^{\prime} 18.96^{\prime \prime} \mathrm{E}$ & 563268.9 & 4621641.6 & 244.1 & 34 & 31 \\
\hline V5 & $41^{\circ} 44^{\prime} 08.72^{\prime \prime} \mathrm{N} ; 21^{\circ} 45^{\prime} 18.37^{\prime \prime} \mathrm{E}$ & 563255.7 & 4621594.0 & 244.5 & 22 & 18 \\
\hline V6 & $41^{\circ} 44^{\prime} 12.04^{\prime \prime} \mathrm{N} ; 21^{\circ} 45^{\prime} 17.50^{\prime \prime} \mathrm{E}$ & 563234.6 & 4621696.2 & 243.9 & 18 & 14 \\
\hline V7 & $41^{\circ} 44^{\prime} 10.49^{\prime \prime} \mathrm{N} ; 21^{\circ} 45^{\prime} 16.12^{\prime \prime} \mathrm{E}$ & 563203.2 & 4621647.9 & 244.4 & 20 & 17 \\
\hline V8 & $41^{\circ} 44^{\prime} 09.88^{\prime \prime} \mathrm{N} ; 21^{\circ} 45^{\prime} 36.22^{\prime \prime} \mathrm{E}$ & 563217.3 & 4621674.5 & 244.0 & 30 & 28 \\
\hline
\end{tabular}

\section{Geodetic measurements}

A geodetic terrain model was created for the metallurgical slag deposit at Veles (Figures 5 and 6) from which detailed information about the shape of the deposit was used to calculate the volume of the slag deposit which was approximately $570,000 \mathrm{~m}^{3}$. This information was used to estimate the volume of material that can be considered for extraction. The bulk density (or volumetric density) was calculated based on the material obtained by core drilling without drilling mud (core hole V-8), which was 2.1 $\mathrm{kg} / \mathrm{m}^{3}$, equivalent to $1,200,000 \mathrm{t}$.

The position of the terrain was measured horizontally and vertically using a GPS-type (LEICA
GS08 GPS /GLONASS Dual-frequency Smart Antenna with CS10 controller) in three sessions. Suitable transformation parameters were used, which were obtained for the appropriate scope by a previous application submitted to the Agency for Real Estate Cadaster, Republic of North Macedonia. Details for each borehole are listed separately in Table 1. Two lists of coordinates and thickness of slag deposit was reported in the local coordinate system and the World Geodetic System (WGS) - a geocentric coordinate system. The total depth (L1) and the thickness (L2) - end of the deposited material are also given in Table 1.

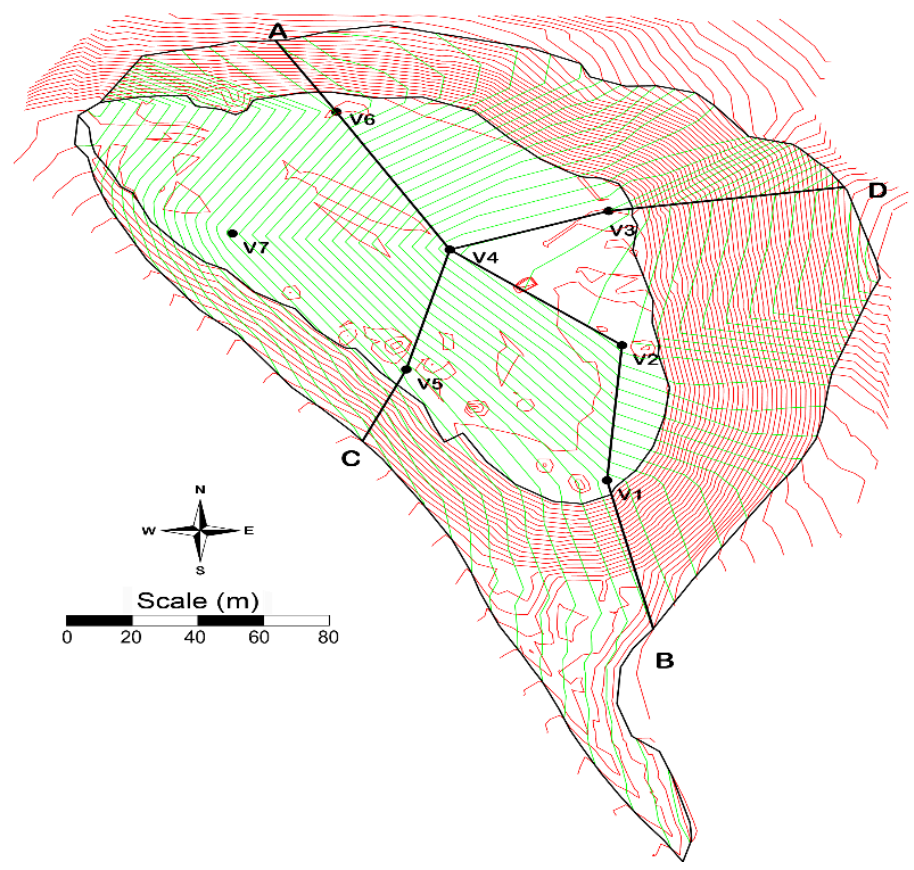

Fig. 5. Geodetic model of the Veles slag deposit showing location of cross sections (A-B and C-D) 


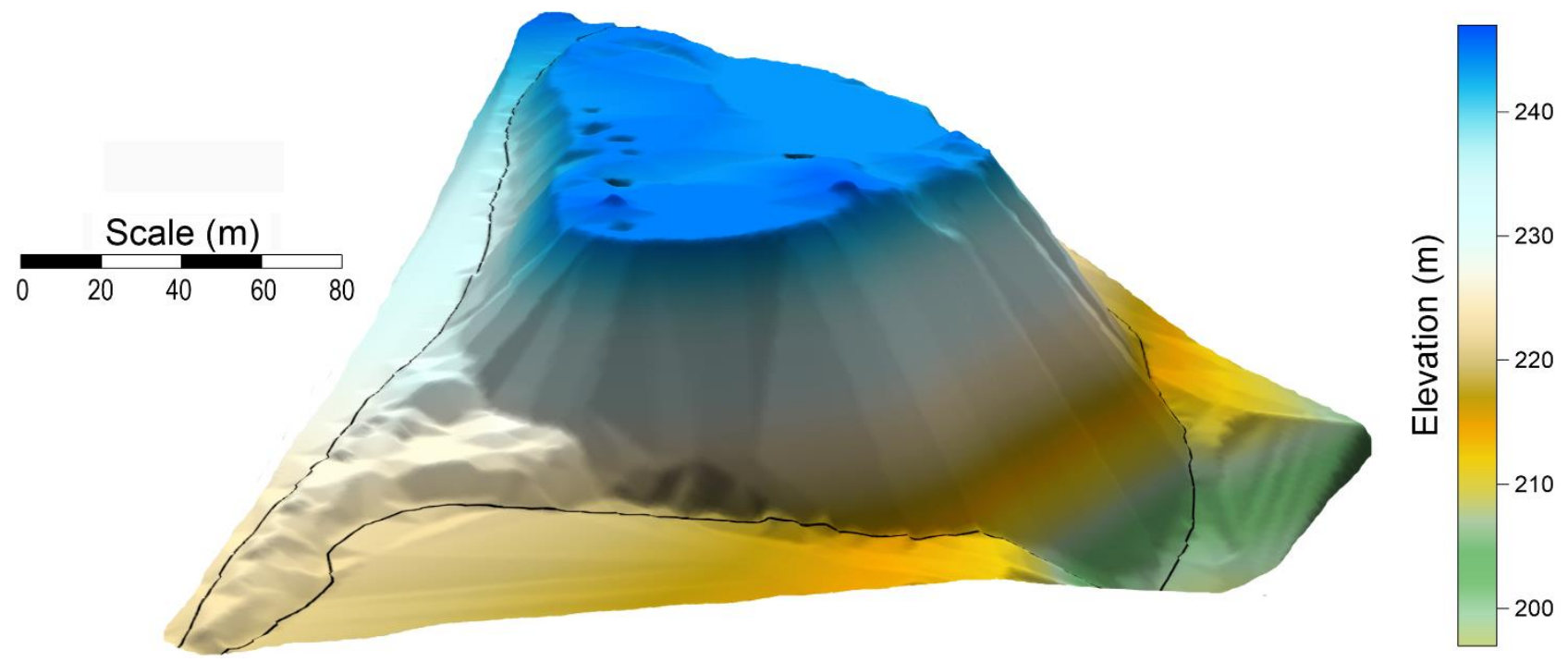

Fig. 6. 3D model of the Veles slag deposit

Granulometric analysis of samples collected from drill hole number V-8 (depth 16 to $38 \mathrm{~m}$ ) was conducted at Civil Engineering Institute in Skopje (Figure 7). The results obtained showed that the grain size was similar at depth; the largest pieces were $10 \mathrm{~mm}$ and the finest granular material was less than $0.08 \mathrm{~mm}$. The average size of $50 \%$ of the material ranged from 1.25 to $4.0 \mathrm{~mm}$ and an average size of $1.4 \mathrm{~mm}$. From the base of the core to $38 \mathrm{~m}$ below the surface, about $65 \%$ of the material had a grain size less than $2 \mathrm{~mm}$ (sand grain); the remaining $35 \%$ of grains were $2 \mathrm{~mm}$ (gravel) in size.

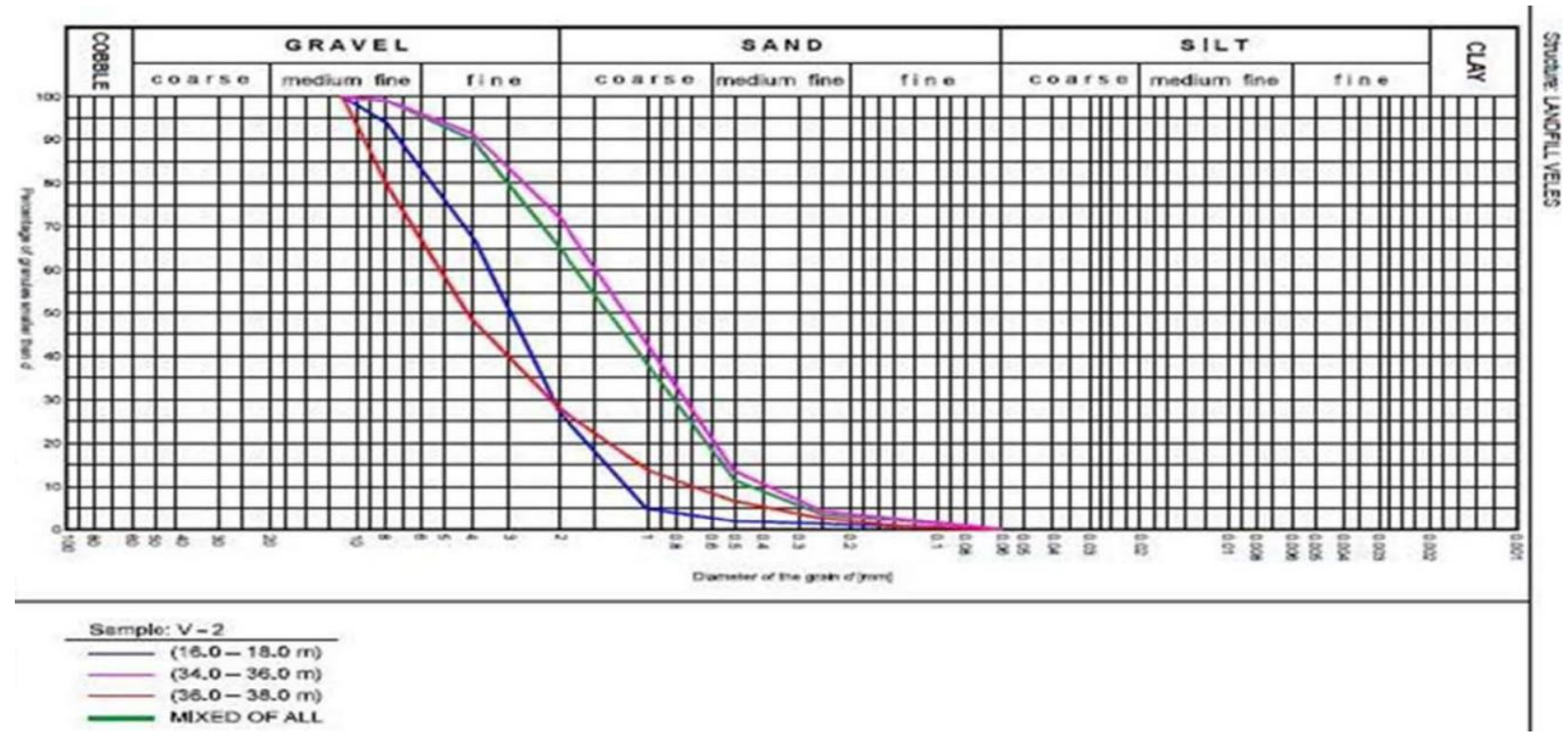

Fig. 7. Particle size distribution

\section{Sample preparation and chemical analysis}

The collected slag and soil samples or mixed slag/soil samples were sent to the Technical Control A.D. in Skopje for grinding to less than 100 micrometers in size. The ground samples were then digested according to the Bureau of Mines digestion meth- od (Morrison Knudsen Corporation, 1992) using $\mathrm{HF}, \mathrm{HNO}_{3}, \mathrm{HCl}$ and $\mathrm{H}_{3} \mathrm{BO}_{3}$ based on the methods developed by Bernas (1968), Langmyhr and Paus (1968), Reid et al. (1970) and Richards (1983).

Procedure. Approximately one gram of finely ground slag sample was weighed and placed in the 
bottom of a $100 \mathrm{ml}$ teflon beaker. Several drops od redistilled water were added to the slag to wet it. The beaker was then clamped to a stand and placed on a heating plate. Then $10 \mathrm{ml}$ of concentrate HF was slowly added to the sample. Digestion (temperature of $80^{\circ} \mathrm{C}$ ) proceeded for 30 to $45 \mathrm{~min}$, during which the temperature was raised to $100^{\circ} \mathrm{C}$. During this time, the beaker was shaken lightly from time to time. When the sample had evaporated to near dryness, a $10 \mathrm{ml}$ solution of an HCL-HF solution was slowly added to the sample. The sample was heated for $90 \mathrm{~min}$ and shaken from time to time. At the end of this period, $90 \mathrm{ml}$ of $4 \%$ boric acid was added to the sample and heated for an additional 60 min. When this phase was completed, the hot solution was rapidly filtered through filter paper into a $50 \mathrm{ml}$ volumetric flask. After filtration, the volumetric flask was filled to the mark with distilled water.

The sample solution was then analyzed using ICP-MS (Agilent 7500 model), according to ISO 17294-2:2016 (ISO 17294-2:2016, 2016). A total of 60 chemical elements were analyzed: $\mathrm{Ag}, \mathrm{Al}, \mathrm{As}$, $\mathrm{Au}, \mathrm{B}, \mathrm{Ba}, \mathrm{Be}, \mathrm{Bi}, \mathrm{Ca}, \mathrm{Cd}, \mathrm{Ce}, \mathrm{Co}, \mathrm{Cr}, \mathrm{Cs}, \mathrm{Cu}, \mathrm{Dy}$, $\mathrm{Er}, \mathrm{Eu}, \mathrm{Fe}, \mathrm{Ga}, \mathrm{Gd}, \mathrm{Ge}, \mathrm{Hf}, \mathrm{Ho}, \mathrm{In}, \mathrm{K}, \mathrm{La}, \mathrm{Li}, \mathrm{Lu}$, $\mathrm{Mg}, \mathrm{Mn}, \mathrm{Mo}, \mathrm{Na}, \mathrm{Nb}, \mathrm{Nd}, \mathrm{Ni}, \mathrm{P}, \mathrm{Pb}, \mathrm{Pd}, \mathrm{Rb}, \mathrm{Re}, \mathrm{S}$, Sb, Sc, Se, Sm, Sn, Sr, Tb, Te, Th, Ti, Tl, Tm, U, V, $\mathrm{W}, \mathrm{Y}, \mathrm{Yb}$ and $\mathrm{Zn}$.

The following multi-element and single-element standard solutions to calibrate the ICP-MS:

- ICP multi-element standard solution, VWR BDH Chemicals, USA, (concentration of $100 \mathrm{mg} / \mathrm{l}$ ) for
$\mathrm{Ag}, \mathrm{As}, \mathrm{B}, \mathrm{Ba}, \mathrm{Bi}, \mathrm{Be}, \mathrm{Ca}, \mathrm{Cd}, \mathrm{Cs}, \mathrm{Co}, \mathrm{Cr}, \mathrm{Cu}$, $\mathrm{Fe}, \mathrm{In}, \mathrm{Li}, \mathrm{Mn}, \mathrm{Mo}, \mathrm{Ni}, \mathrm{Nb}, \mathrm{Pb}, \mathrm{Rb}, \mathrm{Sb}, \mathrm{Se}, \mathrm{Sr}$, $\mathrm{Ti}, \mathrm{Tl}, \mathrm{V}, \mathrm{Zn}$, and $\mathrm{U}$;

- ICP multi-element standard solution IV, Merck, Germany, (concentration of $1000 \mathrm{mg} / \mathrm{l}$ ) for $\mathrm{Al}$, $\mathrm{Ca}, \mathrm{Fe}, \mathrm{In}, \mathrm{K}, \mathrm{Mg}, \mathrm{Mn}, \mathrm{Na}, \mathrm{Zn}$, and $\mathrm{Pb}$;

- multiple element calibration standard (concentration of $10 \mu \mathrm{g} / \mathrm{ml}$ ) for Cs, Dy, Er, Eu, Gd, |Ho, $\mathrm{La}, \mathrm{Lu}, \mathrm{Pr}, \mathrm{Sc}, \mathrm{Sm}, \mathrm{Tb}, \mathrm{Th}, \mathrm{Tm}, \mathrm{Y}$, and $\mathrm{Yb}$;

- 7500 Series PA Tuning 2, Agilent Technologies, USA, (concentration of $10 \mu \mathrm{g} / \mathrm{ml}$ ) for $\mathrm{Ga}, \mathrm{Ge}, \mathrm{Pd}$ and $\mathrm{Sn}$;

- ICP standard solution for P and Re (concentration of $1000 \mathrm{mg} / \mathrm{l}$ ) purchased from Fluka Analytical, Switzerland, a sulfate standard solution (concentration of $1000 \mathrm{mg} / \mathrm{l}$ ) for sulfur from Hach, USA, and $\mathrm{Au}$ (concentration of 1000 mg/l) purchased from Merck, Germany.

The calibration curve was checked every thirtieth measurements by standard solutions at concentrations suitable for each element, and the permissible deviation from the curve was $5 \%$. Each measurement was ranked, and the sequence was as follows: blind test (blank test), solution for verifycation control, control copy, certificate of standard form for composition of light alluvial-deluvial meadow soil PS3 (National Center of Metrology); 1A (by Sardich for $\mathrm{Au}$ ); reference material $320 \mathrm{R}$, calcareous soil, sample Nb0127, CC690 (European Commission), DG JRC, IRMM, ERM (for rare earth elements).

\section{RESULTS AND DISCUSSION}

In the pyrometallurgical production of $\mathrm{Pb}$ and $\mathrm{Zn}$, it is inevitable that significant amounts of these metals will be contained in the slag as a byproduct. The content of $\mathrm{Pb}$ and $\mathrm{Zn}$ in the slag reduce yield and economic efficiency of production and represent a latent danger to the environment and public health. The consequence is that $\mathrm{Pb}$ and $\mathrm{Zn}$ in the slag represent a reduction in the total yield of the metal from the plant. Another consequence is that excessive amounts of $\mathrm{Pb}$ and $\mathrm{Zn}$ content in slag may approach the permissible limit specified by environmental and legal regulations, so the slag cannot be used as a construction material for road or similar type of construction projects. Finally, PTEs in slag pose latent risks to the environment; for example, PTEs are soluble in ground water, and thus easily leached and widely distributed. In the worst case, the slag must be stored as a landfill, which increases cost and further reduces the economic efficiency of the operation (Bohlke et al., 2005; Berdowski et al., 2009); therefore, treatment of slag is sensible and recommended. A suitable slag treatment can increase metal yield and profitability of production and ensure reduction in volume and improved quality of slag suitable for future use in other applications such as construction (Richards, 1983; Bohlke et al., 2005; Berdowski et al., 2009; Voigt, 2014; Jiang et al., 2012; Pietrzyk et al., 2017; Ma et al., 2018). In addition, treated slag has been used to obtain other useful metals other than lead and zinc, and can also be obtained in slag treatment processes (Berdowski et al., 2009; Ettler et al., 2009; Pietrzyk et al., 2017).

For all these reasons, it was important to study the quantity and composition of metallurgical slag deposit in the former lead and zinc smelter at Veles. The collected samples, after their preparation were digested and the solutions were then analyzed using 
ICP-MS. A total of 60 chemical elements were analyzed: Ag, Al, As, Au, B, Ba, Be, Bi, Ca, Cd, Ce, $\mathrm{Co}, \mathrm{Cr}, \mathrm{Cs}, \mathrm{Cu}, \mathrm{Dy}, \mathrm{Er}, \mathrm{Eu}, \mathrm{Fe}, \mathrm{Ga}, \mathrm{Gd}, \mathrm{Ge}, \mathrm{Hf}, \mathrm{Ho}$, In, K, La, Li, Lu, Mg, Mn, Mo, Na, Nb, Ni, P, Pb, $\mathrm{Pd}, \mathrm{Rb}, \mathrm{Re}, \mathrm{S}, \mathrm{Sb}, \mathrm{Sc}, \mathrm{Se}, \mathrm{Sm}, \mathrm{Sn}, \mathrm{Sr}, \mathrm{Tb}, \mathrm{Te}, \mathrm{Th}$, $\mathrm{Ti}, \mathrm{Tl}, \mathrm{Tm}, \mathrm{U}, \mathrm{V}, \mathrm{W}, \mathrm{Y}, \mathrm{Yb}$ and $\mathrm{Zn}$. The results obtained for the mean content of all elements analyzed are given in Table 2. Table 3 shows the average, minimum and maximum contents and potential amount of each element analyzed in the metallurgical slag deposit at Veles.

As can be seen from the results in Tables 2 and 3 , the composition of the slag in the landfill is very inhomogeneous. The reason for this diversity in composition is that slag from the total production of lead and zinc at the smelter was deposited here over a period of about 30 years before its closure in 2002. In addition to $\mathrm{Pb}$ and $\mathrm{Zn}$, there were plants that produced $\mathrm{Cd}, \mathrm{Ag}$, and $\mathrm{Au}$; therefore, the occurrence of these and other important metals should be investigated for potential recovery through additional processing of slag to neutralize their toxicity and the pollution they cause. In addition to $\mathrm{Pb}, \mathrm{Zn}, \mathrm{Cd}$ and
Ag (Figure 8), the following metals were also analyzed: As, Be, Bi, Cu, Fe, In, Mn, Nb, Pd, Sb, Se, $\mathrm{Sn}, \mathrm{Te}$ and $\mathrm{Tl}$, as well as $\mathrm{S}$, because of its high content in the Veles landfill $(6.13 \%$ on average and ranging from 0.186 to $20 \%$ with a potential of 73,000 t (Table 2, Figure 9).

Note that the $\mathrm{Zn}$ content is very high (Tables 2 and 3 ) with an average content of $9.6 \%$, and a range from 5.6 to $14 \%$. Figure 8 shows that the highest $\mathrm{Zn}$ content was found in the southern part of the landfill (boreholes V-1 and V-2) with a content of over $11 \%$. The total amount of $\mathrm{Zn}$ was close to $120,000 \mathrm{t}$, with the potential for significant economic benefit in the recovery of slag from this deposit. The $\mathrm{Pb}$ content was also considerable, the average content was $2.4 \%$ (with absolute values ranges from 0.55 to $16 \%$, with a potential quantity of 29,000 t) (Table 3). Quantities of silver and cadmium were 40 and $60 \mathrm{t}$. High contents of $\mathrm{Pb}$, as well as $\mathrm{Ag}$ and $\mathrm{Cd}$, were found in the eastern part of the landfill (V-3) and the central part of the deposit $(\mathrm{V}-4)$ with a content exceeding $4 \%$.

\section{Table 2}

Average contents of elements analyzed in slag samples collected within $10 \mathrm{~m}$ of each borehole in the MHK Zletovo slag deposit

\begin{tabular}{|c|c|c|c|c|c|c|c|c|c|c|c|c|c|c|c|c|}
\hline Element & nit & $\begin{array}{c}\text { V-1 } \\
(0-10)\end{array}$ & $\begin{array}{c}\text { V-1 } \\
(10-20)\end{array}$ & $\begin{array}{c}\mathrm{V}-2 \\
(0-10)\end{array}$ & $\begin{array}{c}\mathrm{V}-2 \\
(10-20)\end{array}$ & $\begin{array}{c}\mathrm{V}-2 \\
(20-30)\end{array}$ & $\begin{array}{c}\mathrm{V}-3 \\
(0-10)\end{array}$ & $\begin{array}{c}\mathrm{V}-3 \\
(10-20)\end{array}$ & $\begin{array}{c}\text { V-3 } \\
(20-30)\end{array}$ & $\begin{array}{c}\text { V-4 } \\
(0-10)\end{array}$ & $\begin{array}{c}\mathrm{V}-4 \\
(10-20)\end{array}$ & $\begin{array}{c}\mathrm{V}-4 \\
(20-30)\end{array}$ & $\begin{array}{c}\text { V-5 } \\
(0-10)\end{array}$ & $\begin{array}{c}\text { V-5 } \\
(10-20)\end{array}$ & $\begin{array}{c}\text { V-6 } \\
(0-10)\end{array}$ & $\begin{array}{c}\mathrm{V}-7 \\
(0-10)\end{array}$ \\
\hline $\mathrm{g}$ & & 34 & 24 & 22 & 200 & 19 & 38 & 75 & 79 & 60 & 21 & 20 & 59 & 52 & 5 & 45 \\
\hline$\Delta 1$ & $y$ & 34 & 31 & 19 & 7 & 17 & 36 & 37 & 37 & 30 & 30 & 4.0 & 4.0 & 40 & 1 & 3.8 \\
\hline As & $\%$ & 0.37 & & & 0.22 & 0.19 & 0.63 & 0.28 & & & 0.45 & 0.69 & 0.54 & 0.56 & 0.92 & 0.37 \\
\hline 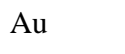 & 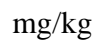 & 1.0 & 10 & 1 & 10 & 1 & 10 & 1. & 23 & 10 & 1.0 & 1.0 & 1.0 & 1.0 & 1.0 & 1.0 \\
\hline B & 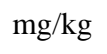 & 170 & 130 & 10 & 0 & 10 & 260 & 110 & 100 & 73 & 63 & 10 & 2800 & 10 & 10 & 10 \\
\hline B & $\%$ & 0.29 & 0.17 & 0.25 & 0.06 & 0.14 & 0.37 & 0.23 & 0.17 & 0.45 & 0.18 & 0.16 & 0.65 & 0.42 & 0.61 & 0.42 \\
\hline $\mathrm{Be}$ & $\mathrm{m}$ & 3 & 3.7 & 3.6 & 5 & 3.8 & 56 & 5 & 4 & 4 & 4 & 4.7 & 3.8 & 41 & 4 & 4.2 \\
\hline B & $\mathrm{mg} / \mathrm{kg}$ & 22 & 8.6 & 14 & 58.1 & 9.1 & 27 & 120 & 72.3 & 31 & 26 & 48 & 29.8 & 28 & 37 & 27 \\
\hline C & $\%$ & 8.9 & 8.6 & 8 & 7.3 & 7.0 & 9 & 10 & 10.8 & 13 & 1 & 9. & 9 & 1 & 12 & 12 \\
\hline $\mathrm{Cd}$ & $\mathrm{mg} / \mathrm{kg}$ & 4.8 & 5.2 & 19 & 110 & 57 & 62 & 92 & 38.3 & 21 & 6.9 & 46 & 46.3 & 12 & 12 & 6.3 \\
\hline $\mathrm{Ce}$ & $\mathrm{mg} / \mathrm{kg}$ & 16 & 40 & 41 & 45.2 & 47 & 52 & 69 & 67. & 02 & 72 & 64 & 01.1 & 64 & 58 & 55 \\
\hline Co & $\mathrm{mo} / \mathrm{kg}$ & 380 & 170 & 200 & 71.3 & 93 & 210 & 110 & 140 & 150 & 140 & 100 & 160 & 160 & 360 & 240 \\
\hline $\mathrm{Cr}$ & $\mathrm{mg} / \mathrm{kg}$ & 270 & 250 & 250 & 220 & 200 & 480 & 490 & 610 & 420 & 510 & 550 & 470 & 640 & 300 & 430 \\
\hline Cs & $/ \mathrm{kg}$ & & 0 & & 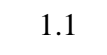 & 0 & 3 & 1.6 & & 7 & 16 & 2. & 1.7 & 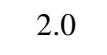 & 0 & 1.6 \\
\hline $\mathrm{Cu}$ & $\%$ & 0.63 & 0.47 & 0.37 & 0.48 & 0.39 & 2.6 & 0.91 & 0.86 & 0.94 & 1.3 & 1.0 & 0.53 & 0.93 & 0.65 & 0.75 \\
\hline Dy & $\mathrm{mg} / \mathrm{kg}$ & 4.0 & 5.0 & 4.3 & 4.1 & 4.7 & 5.9 & 6.5 & 6 & 5.6 & 6.2 & 6.3 & 5.7 & 6.9 & 6.8 & 7.0 \\
\hline $\mathrm{Er}$ & $\mathrm{mg} / \mathrm{kg}$ & 3.0 & 3 & 2 & 2.6 & 3.1 & 2.9 & 3.1 & 3. & 4.3 & 4.9 & 4.8 & 3.4 & 4.0 & 3.9 & 4.3 \\
\hline $\mathrm{Eu}$ & $\mathrm{mg} / \mathrm{kg}$ & 2.3 & 1.8 & 1.9 & 1.1 & 1.7 & 2.7 & 2.2 & 2.1 & 2.8 & 2.4 & 2.4 & 2.9 & 3.2 & 3.2 & 2.0 \\
\hline $\mathrm{Fe}$ & $\%$ & 24 & 25 & 23 & 21.0 & 18 & 28 & 28 & 29.2 & 29 & 28 & 29 & 28.9 & 31 & 42 & 30 \\
\hline
\end{tabular}


T a b le 2 (continues)

\begin{tabular}{|c|c|c|c|c|c|c|c|c|c|c|c|c|c|c|c|c|}
\hline Element & Unit & $\begin{array}{c}\mathrm{V}-1 \\
(0-10)\end{array}$ & $\begin{array}{c}\mathrm{V}-1 \\
(10-20)\end{array}$ & $\begin{array}{c}\mathrm{V}-2 \\
(0-10)\end{array}$ & $\begin{array}{c}\mathrm{V}-2 \\
(10-20)\end{array}$ & $\begin{array}{c}\mathrm{V}-2 \\
(20-30)\end{array}$ & $\begin{array}{c}\mathrm{V}-3 \\
(0-10)\end{array}$ & $\begin{array}{c}\mathrm{V}-3 \\
(10-20)\end{array}$ & $\begin{array}{c}\mathrm{V}-3 \\
(20-30)\end{array}$ & $\begin{array}{c}\mathrm{V}-4 \\
(0-10)\end{array}$ & $\begin{array}{c}V-4 \\
(10-20)\end{array}$ & $\begin{array}{c}\mathrm{V}-4 \\
(20-30)\end{array}$ & $\begin{array}{c}\mathrm{V}-5 \\
(0-10)\end{array}$ & $\begin{array}{c}\mathrm{V}-5 \\
(10-20)\end{array}$ & $\begin{array}{c}\mathrm{V}-6 \\
(0-10)\end{array}$ & $\begin{array}{c}\mathrm{V}-7 \\
(0-10)\end{array}$ \\
\hline 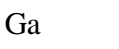 & $\mathrm{mg} / \mathrm{kg}$ & 100 & 28 & 35 & 28.3 & 26 & 73 & 45 & 65.1 & 120 & 59 & 93 & 110 & 47 & 150 & 70 \\
\hline Gd & $\mathrm{g} / \mathrm{kg}$ & 4.7 & 5 & 4.5 & 4 & 4.8 & 6.9 & 8 & 8.0 & 5.7 & 6.9 & 6.3 & 6.3 & 1.0 & 7.3 & 6.6 \\
\hline Ge & $\mathrm{mg} / \mathrm{kg}$ & 1.0 & 1.0 & 1.0 & 1.0 & 1.0 & 1.0 & 1.1 & 1.0 & 2.1 & 1.1 & 1.0 & 1.3 & 2.6 & 2.2 & 1.3 \\
\hline $\mathrm{Hf}$ & $\mathrm{mg} / \mathrm{kg}$ & 2.6 & 3.4 & 2.2 & 2.2 & 1.9 & 1.7 & 2.5 & 2.2 & 3.2 & 4.3 & 2.9 & 3.2 & 2.9 & 2.7 & 2.9 \\
\hline Ho & $\mathrm{h} / \mathrm{kg}$ & 1.4 & 1.5 & 1.1 & 1.1 & 1.3 & 1.4 & 1.5 & 1.5 & 1.5 & 1.8 & 1.8 & 1.2 & 1.4 & 1.4 & 1.4 \\
\hline In & $\mathrm{mg} / \mathrm{kg}$ & 1.2 & 1.0 & 1.0 & 1.0 & 1.0 & 1.6 & 1.5 & 1.6 & 3.8 & 2.5 & 3.3 & 11.9 & 5.4 & 10 & 4.8 \\
\hline K & $\%$ & 0.53 & 0.42 & 0.58 & 0.50 & 0.46 & 0.65 & 0.70 & 0.69 & 0.84 & 0.79 & 0.80 & 0.88 & 0.86 & 1.0 & 0.80 \\
\hline $\mathrm{La}$ & $\mathrm{mg} / \mathrm{kg}$ & 40 & 47 & 41 & 39 & 37 & 27 & 36 & 35 & 32 & 37 & 33 & 34 & 40 & 36 & 44 \\
\hline $\mathrm{Li}$ & $\mathrm{mg} / \mathrm{kg}$ & 34 & 35 & 28 & 26 & 18 & 2.3 & 1.0 & 1.0 & 73 & 46 & 18 & 53 & 64 & 30 & 58 \\
\hline $\mathrm{Lu}$ & $\mathrm{mg} / \mathrm{kg}$ & 1.0 & 1.0 & 1.0 & 1.0 & 1.0 & 1.0 & 1.0 & 1.0 & 1.0 & 1.0 & 1.0 & 1.0 & 1.0 & 1.0 & 1.0 \\
\hline $\mathrm{Mg}$ & $\%$ & 0.77 & 0.99 & 7.9 & 6.8 & 7.8 & 1.5 & 1.2 & 1.4 & 1.7 & 1.5 & 1.6 & 1.9 & 1.7 & 2.7 & 1.5 \\
\hline $\mathrm{Mn}$ & $\%$ & 0.78 & 1.3 & 0.61 & 0.62 & 0.51 & 0.95 & 1.1 & 0.94 & 0.86 & 0.92 & 0.82 & 1.1 & 1.4 & 1.5 & 1.2 \\
\hline Mo & $\mathrm{mg} / \mathrm{kg}$ & 19 & 14 & 39 & 43 & 44 & 51 & 78 & 60.2 & 45 & 65 & 68 & 39 & 65 & 40 & 67 \\
\hline $\mathrm{Na}$ & $\%$ & 0.52 & 0.36 & 0.23 & 0.18 & 0.09 & 0.92 & 0.94 & 0 & 1.7 & 1.8 & 1.8 & 1.8 & 3.0 & 4.1 & 1.5 \\
\hline $\mathrm{Nb}$ & $\mathrm{mg} / \mathrm{kg}$ & 8.6 & 11 & 12 & 9.4 & 10 & 13 & 31 & 13.7 & 16 & 18 & 17 & 13.8 & 15 & 13 & 14 \\
\hline $\mathrm{Nd}$ & 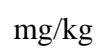 & 22 & 25 & 22 & 20.7 & 22 & 20 & 26 & 25 & 26 & 31 & 27 & 26 & 29 & 26 & 28 \\
\hline $\mathrm{Ni}$ & $\mathrm{mg} / \mathrm{kg}$ & 300 & 84 & 86 & 35 & 34 & 470 & 340 & 490 & 230 & 260 & 260 & 260 & 250 & 360 & 270 \\
\hline $\mathrm{P}$ & $\%$ & 0.17 & 7 & 0.16 & 0.16 & 0.10 & 0.19 & 0.20 & 0.18 & 0.20 & 0.25 & 0.20 & 0.25 & 0.27 & 0.29 & 0.20 \\
\hline $\mathrm{Pb}$ & $\%$ & 2.0 & 1.8 & 1.6 & 1.8 & 0.84 & 5.0 & 3.3 & 3.8 & 3.7 & 2.7 & 2.9 & 2.1 & 2.4 & 2.2 & 1.9 \\
\hline $\mathrm{Pd}$ & ming/Kg & 1.2 & 2.7 & 3.0 & 0.3 & 4.5 & 4.1 & 2.0 & 3.0 & 2.5 & 2.2 & 1.6 & 3.7 & 4.9 & 4.5 & 4.2 \\
\hline $\mathrm{Rb}$ & $\mathrm{mg} / \mathrm{kg}$ & 35 & 29 & 32 & 20.4 & 21 & 28 & 28 & 29 & 36 & 32 & 32 & 35.7 & 32 & 34 & 25 \\
\hline $\operatorname{Re}$ & $\mathrm{mg} / \mathrm{kg}$ & 1.0 & 1.0 & 1.0 & 1.0 & 1.0 & 1.0 & 1.0 & 1.0 & 1.0 & 1.0 & 1.0 & 1.0 & 1.0 & 1.0 & 1.0 \\
\hline S & $\%$ & 1.4 & 1.3 & 3.0 & 3.2 & 3.4 & 0.20 & 0.22 & 0.27 & 13 & 15 & 13 & 10.3 & 14 & 14 & 0.84 \\
\hline $\mathrm{Sb}$ & $\mathrm{mg} / \mathrm{kg}$ & 480 & 190 & 660 & 500 & 260 & 910 & 550 & 1000 & 130 & 100 & 130 & 270 & 200 & 350 & 110 \\
\hline Sc & $\mathrm{mg} / \mathrm{kg}$ & 11 & 9.4 & 8.1 & 5 & 7 & 8. & 8 & 0 & 10 & 10 & 1 & 27.1 & 16 & 15 & 10 \\
\hline $\mathrm{Se}$ & $\mathrm{mg} / \mathrm{kg}$ & 25 & 1 & 31 & 29.1 & 20 & 60 & 84 & 47.1 & 47 & 44 & 39 & 40.9 & 78 & 93 & 88 \\
\hline $\mathrm{Sm}$ & n's & 5.1 & 5.2 & 5.4 & T.J & 5.4 & 7. & o & 1 & 70 & 7 & 6. & 7 & 8 & 8.6 & 7.8 \\
\hline $\mathrm{Sn}$ & $\mathrm{mg} / \mathrm{kg}$ & 250 & 40 & 180 & 52.8 & 11 & 410 & 140 & 170 & 280 & 100 & 76 & 620 & 130 & 550 & 200 \\
\hline SI & IIIg/Kg & 380 & 300 & 330 & 230 & 340 & 480 & 380 & 340 & 660 & 530 & 590 & 470 & 390 & 580 & 790 \\
\hline $\mathrm{Tb}$ & $\mathrm{mg} / \mathrm{kg}$ & 1.0 & 1.0 & 1.0 & 1.0 & 1.0 & 1.0 & 1.0 & 1.0 & 1.0 & 1.1 & 1.1 & 1.0 & 1.1 & 1.0 & 1.3 \\
\hline $1 \mathrm{e}$ & $\mathrm{mg} / \mathrm{kg}$ & 2.7 & 1.8 & 2.5 & 1.0 & 1.4 & 4.0 & 2.4 & 1.9 & 3.7 & 1.8 & 1.6 & 5.4 & 3.6 & 5.0 & 3.1 \\
\hline Th & $\mathrm{mg} / \mathrm{kg}$ & 8 & 84 & 74 & 67 & 70 & 76 & 8.6 & 8.8 & 10 & 11 & 9.7 & 9.7 & 11 & 9.5 & 9.3 \\
\hline $\mathrm{Ti}$ & $\%$ & 0.26 & 0.26 & 0.29 & 0.27 & 0.26 & 0.28 & 0.35 & 0.32 & 0.26 & 0.29 & 0.27 & 0.31 & 0.34 & 0.37 & 0.31 \\
\hline $\mathrm{T}$ & $\mathrm{mg} / \mathrm{kg}$ & 5.0 & 2.0 & 9.6 & 9.6 & 7.3 & 21 & 28 & 22.3 & 18 & 12 & 13 & 44.1 & 100 & 27 & 1.7 \\
\hline $\mathrm{Tm}$ & $\mathrm{mg} / \mathrm{kg}$ & 1.0 & 1.0 & 1.0 & 1.0 & 1.0 & 1.0 & 1.0 & 1.0 & 1.0 & 1.0 & 1.0 & 1.0 & 1.1 & 1.1 & 1.0 \\
\hline $\mathrm{U}$ & $\mathrm{mg} / \mathrm{kg}$ & 12 & 8.8 & 8.0 & 7.0 & 12 & 7.8 & 13 & 9.2 & 8.5 & 10 & 12 & 10.1 & 16 & 12 & 16 \\
\hline V & $\mathrm{mg} / \mathrm{kg}$ & 140 & 110 & 120 & 90 & 99 & 120 & 150 & 120 & 130 & 140 & 130 & 120 & 140 & 160 & 130 \\
\hline w & $\mathrm{mg} / \mathrm{kg}$ & 31 & 10 & 27 & 17.6 & 18 & 1.0 & 1.0 & 1.0 & 18 & 11 & 15 & 36.8 & 19 & 39 & 22 \\
\hline $\mathrm{Y}$ & $\mathrm{mg} / \mathrm{kg}$ & 29 & 33 & 26 & 25.8 & 30 & 32 & 36 & 35.7 & 34 & 41 & 42 & 37.0 & 46 & 47 & 39 \\
\hline $\mathrm{Yb}$ & mg/kg & 2.3 & 2.6 & 2.0 & 2.1 & 2.4 & 3.1 & 3.5 & 3.6 & 2.6 & 3.1 & 3.0 & 4.1 & 4.6 & 4.4 & 3.1 \\
\hline $\mathrm{Zn}$ & $\%$ & 11 & 9.2 & 13 & 11.3 & 9.8 & 8.5 & 8.8 & 8.1 & 8.6 & 9.6 & 8.3 & 9.7 & 9.5 & 11 & 9.1 \\
\hline
\end{tabular}


Ta b l e 3

Mean, minimum and maximum contents and potential quantity of elements analyzed in slag samples from the MHK Zletovo slag deposit

\begin{tabular}{|c|c|c|c|c|c|c|c|c|c|c|c|}
\hline Element & Unit & Mean & Minimum & Maximum & $\begin{array}{c}\text { Potential } \\
\text { quantity }(\mathrm{t})\end{array}$ & Element & Unit & Mean & Minimum & Maximum & $\begin{array}{c}\text { Potential } \\
\text { quantity }(\mathrm{t})\end{array}$ \\
\hline $\mathrm{Ag}$ & $\mathrm{mg} / \mathrm{kg}$ & 51 & 6.9 & 930 & 61 & Mo & $\mathrm{mg} / \mathrm{kg}$ & 48 & 9.5 & 170 & 57 \\
\hline $\mathrm{Al}$ & $\%$ & 3.4 & 1.6 & 5.9 & 41,000 & $\mathrm{Na}$ & $\%$ & 1.3 & 0.020 & 4.6 & 16,000 \\
\hline As & $\%$ & 0.42 & 0.009 & 1.2 & 5,000 & $\mathrm{Nb}$ & $\mathrm{mg} / \mathrm{kg}$ & 14 & 5.0 & 90 & 17 \\
\hline $\mathrm{Ba}$ & $\%$ & 0.31 & 0.047 & 1.0 & 3,700 & $\mathrm{Nd}$ & $\mathrm{mg} / \mathrm{kg}$ & 25 & 16 & 40 & 30 \\
\hline $\mathrm{Be}$ & $\mathrm{mg} / \mathrm{kg}$ & 4.4 & 2.7 & 14 & 5.3 & $\mathrm{Ni}$ & $\mathrm{mg} / \mathrm{kg}$ & 240 & $<1.0$ & 630 & 280 \\
\hline $\mathrm{Bi}$ & $\mathrm{mg} / \mathrm{kg}$ & 36 & $<1.0$ & 510 & 43 & $\mathrm{P}$ & $\%$ & 0.21 & 0.077 & 0.35 & 2,500 \\
\hline $\mathrm{Ca}$ & $\%$ & 9.9 & 6.2 & 22 & 120,000 & $\mathrm{~Pb}$ & $\%$ & 2.4 & 0.55 & 16 & 29,000 \\
\hline $\mathrm{Cd}$ & $\mathrm{mg} / \mathrm{kg}$ & 34 & $<1.0$ & 500 & 40 & $\mathrm{Pd}$ & $\mathrm{mg} / \mathrm{kg}$ & 3.1 & $<1.0$ & 14 & 3.8 \\
\hline $\mathrm{Ce}$ & $\mathrm{mg} / \mathrm{kg}$ & 56 & 40 & 110 & 67 & $\mathrm{Rb}$ & $\mathrm{mg} / \mathrm{kg}$ & 30 & 17 & 44 & 35 \\
\hline Co & $\mathrm{mg} / \mathrm{kg}$ & 170 & 41 & 560 & 210 & $S$ & $\%$ & 6.1 & 0.19 & 20 & 73,000 \\
\hline $\mathrm{Cr}$ & $\mathrm{mg} / \mathrm{kg}$ & 390 & $<1.0$ & 980 & 460 & $\mathrm{Sb}$ & $\mathrm{mg} / \mathrm{kg}$ & 370 & 35 & 2100 & 440 \\
\hline Cs & $\mathrm{mg} / \mathrm{kg}$ & 1.6 & $<1.0$ & 2.7 & 1.9 & $\mathrm{Sc}$ & $\mathrm{mg} / \mathrm{kg}$ & 11 & 6.3 & 97 & 13 \\
\hline $\mathrm{Cu}$ & $\%$ & 1.3 & 0.17 & 11 & 16,000 & $\mathrm{Se}$ & $\mathrm{mg} / \mathrm{kg}$ & 49 & $<1.0$ & 220 & 59 \\
\hline Dy & $\mathrm{mg} / \mathrm{kg}$ & 5.7 & 3.8 & 8.6 & 6.9 & $\mathrm{Sm}$ & $\mathrm{mg} / \mathrm{kg}$ & 6.9 & 4.3 & 11 & 8.2 \\
\hline $\mathrm{Er}$ & $\mathrm{mg} / \mathrm{kg}$ & 3.6 & 2.2 & 5.3 & 4.3 & Sn & $\mathrm{mg} / \mathrm{kg}$ & 210 & 5.2 & 1,000 & 250 \\
\hline $\mathrm{Eu}$ & $\mathrm{mg} / \mathrm{kg}$ & 2.3 & 1.0 & 4.3 & 2.7 & $\mathrm{Sr}$ & $\mathrm{mg} / \mathrm{kg}$ & 460 & 230 & 1,100 & 550 \\
\hline $\mathrm{Fe}$ & $\%$ & 28 & 16 & 50 & 330,000 & $\mathrm{Te}$ & $\mathrm{mg} / \mathrm{kg}$ & 2.8 & $<1.0$ & 8.1 & 3.3 \\
\hline $\mathrm{Ga}$ & $\mathrm{mg} / \mathrm{kg}$ & 70 & 18 & 190 & 84 & Th & $\mathrm{mg} / \mathrm{kg}$ & 8.9 & 6.3 & 13 & 11 \\
\hline $\mathrm{Gd}$ & $\mathrm{mg} / \mathrm{kg}$ & 6.2 & 4.2 & 10 & 7.4 & $\mathrm{Ti}$ & $\%$ & 0.30 & 0.22 & 0.44 & 3,500 \\
\hline Hf & $\mathrm{mg} / \mathrm{kg}$ & 2.7 & 1.2 & 5.0 & 3.2 & $\mathrm{Tl}$ & $\mathrm{mg} / \mathrm{kg}$ & 19 & $<1.0$ & 200 & 22 \\
\hline Ho & $\mathrm{mg} / \mathrm{kg}$ & 1.4 & $<1.0$ & 2.2 & 1.7 & $\mathrm{U}$ & $\mathrm{mg} / \mathrm{kg}$ & 11 & 5.6 & 29 & 13 \\
\hline In & $\mathrm{mg} / \mathrm{kg}$ & 3.4 & $<1.0$ & 17 & 4.1 & V & $\mathrm{mg} / \mathrm{kg}$ & 130 & 84 & 250 & 150 \\
\hline $\mathrm{K}$ & $\%$ & 0.70 & 0.39 & 1.2 & 8,300 & W & $\mathrm{mg} / \mathrm{kg}$ & 18 & $<1.0$ & 57 & 22 \\
\hline $\mathrm{La}$ & $\mathrm{mg} / \mathrm{kg}$ & 37 & 22 & 59 & 44 & Y & $\mathrm{mg} / \mathrm{kg}$ & 36 & 24 & 57 & 43 \\
\hline $\mathrm{Li}$ & $\mathrm{mg} / \mathrm{kg}$ & 32 & $<1.0$ & 95 & 38 & $\mathrm{Yb}$ & $\mathrm{mg} / \mathrm{kg}$ & 3.1 & 1.9 & 6.0 & 3.7 \\
\hline $\mathrm{Mg}$ & $\%$ & 2.8 & 0.64 & 10 & 33,000 & $\mathrm{Zn}$ & $\%$ & 9.6 & 5.6 & 14 & 120,000 \\
\hline $\mathrm{Mn}$ & $\%$ & 0.99 & 0.42 & 1.9 & 12,000 & & & & & & \\
\hline
\end{tabular}
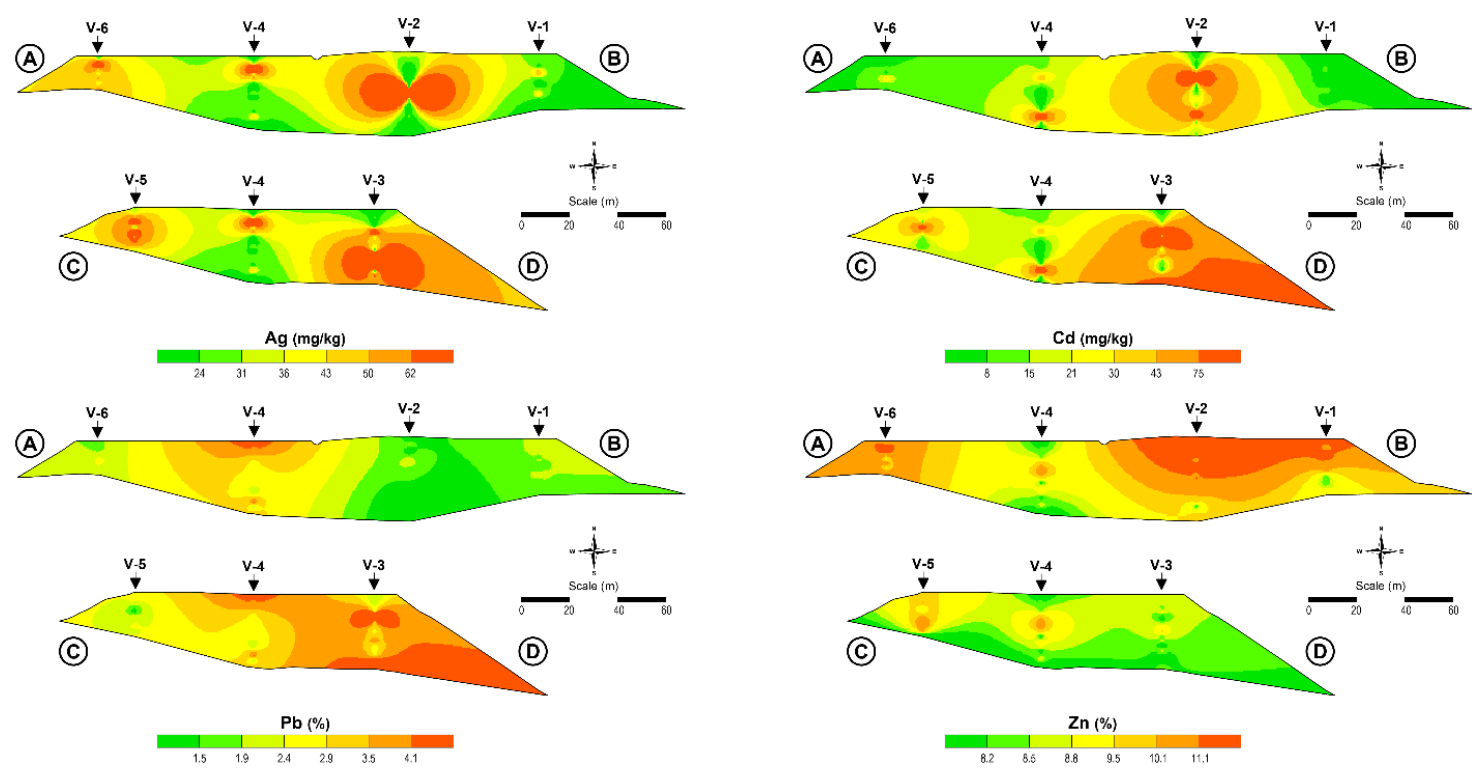

Fig. 8. Distribution of $\mathrm{Ag}, \mathrm{Cd}, \mathrm{Pb}$ and $\mathrm{Zn}$ in the Veles slag deposit (cross sections $\mathrm{A}-\mathrm{B}$ and $\mathrm{C}-\mathrm{D}$ ); (see Fig. 5 for location of cross sections A-B and C-D) 
The distribution of the other metals present (As, Be, Bi, Cu, Fe, In, Mn, Pd, Sb, Se, Sn, Te, and $\mathrm{Tl}$ ) in the Veles slag heap are shown in Figure 9. The highest content of most elements (As, Fe, In, Mn, Nb, S, Se, Sn, Te, and Tl) was observed in the central (V-4) and northern part (V-6) of the landfill. Of the se elements, the most precious metals (In, Pd, Se, Te and $\mathrm{Tl}$ ) deserve special attention. There are relatively large quantities of In $(4.1 \mathrm{t}), \mathrm{Nb}(17 \mathrm{t}), \mathrm{Pb}$ (3.8 t), Se (59 t), Te (3.3 t) and Tl (of $22 \mathrm{t}$ ). Due to the high content of iron and copper in the slag, these elements also deserve attention, because the calculations indicate potential quantities of $330,000 \mathrm{t}$ and $16,000 \mathrm{t}$, respectively
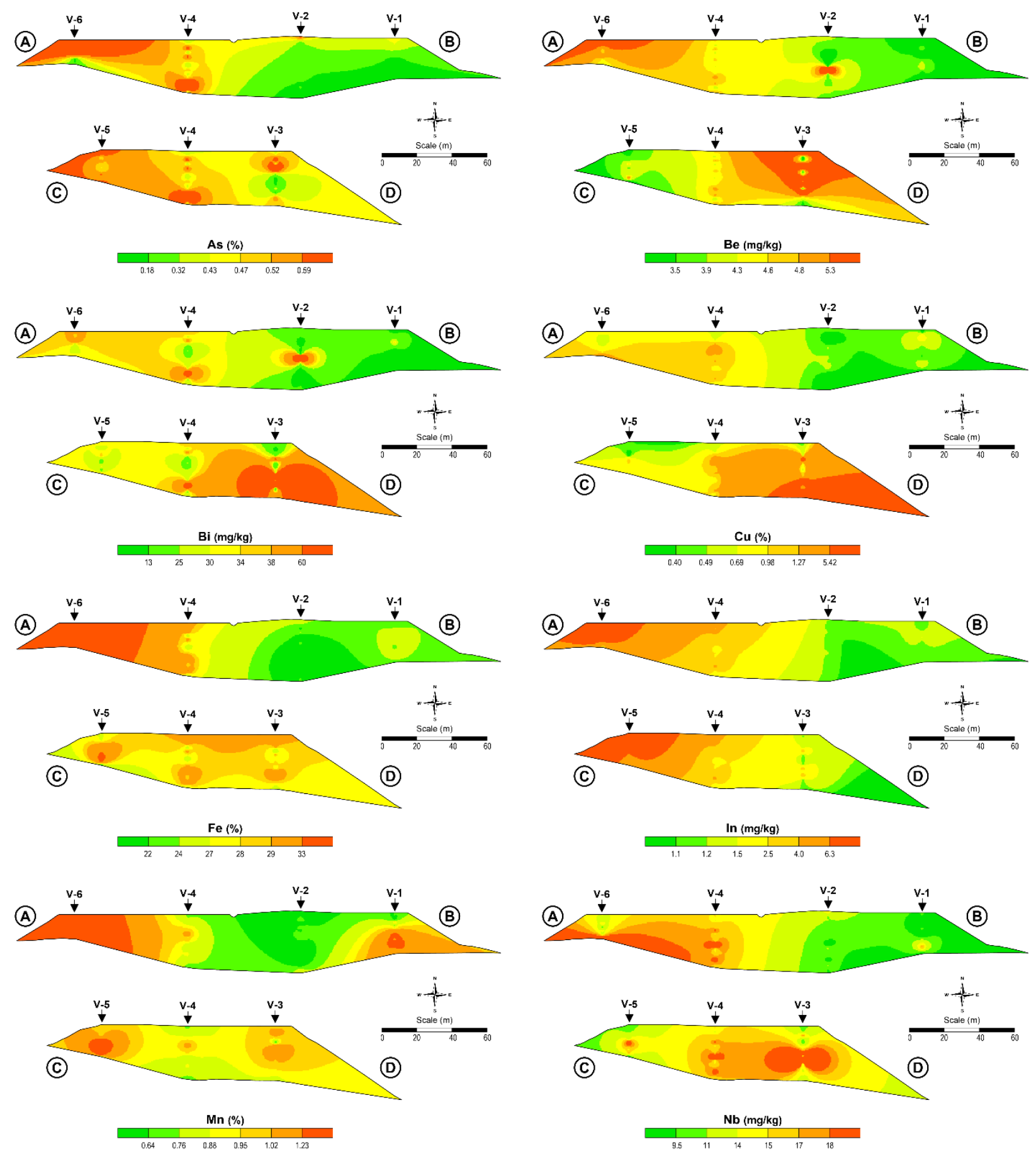

(Fig. 9) 

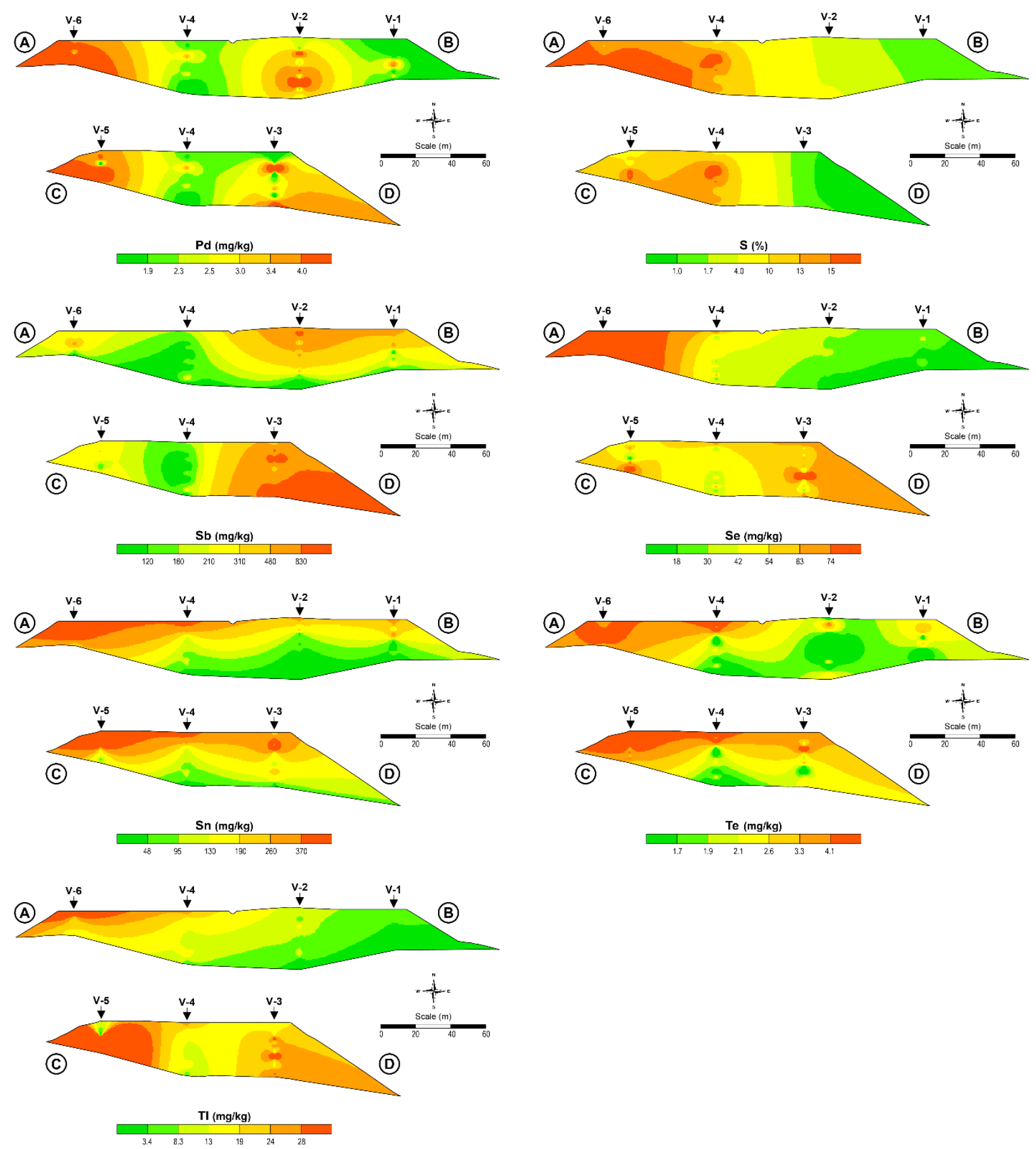

Fig. 9. Distribution of $\mathrm{As}, \mathrm{Be}, \mathrm{Bi}, \mathrm{Cu}, \mathrm{Fe}, \mathrm{In}, \mathrm{Mn}, \mathrm{Nd}, \mathrm{Pd}, \mathrm{S}, \mathrm{Sb}, \mathrm{Se}, \mathrm{Sn}, \mathrm{Te}$ and $\mathrm{Tl}$ in the Veles slag deposit (cross sections A-B and C-D); (see Fig. 5 for location of cross sections A-B and C-D)

The following rare earth elements (REEs) were also analyzed: $\mathrm{Ce}, \mathrm{Dy}, \mathrm{Er}, \mathrm{Eu}, \mathrm{Gd}, \mathrm{Ho}, \mathrm{La}, \mathrm{Nd}$, $\mathrm{Sc}, \mathrm{Sm}, \mathrm{Y}$ and $\mathrm{Yb}$. The results presented in Table 3 show that the contents of these elements are noticeable, especially the меан contents of Ce $(56 \mathrm{mg} / \mathrm{kg})$, $\mathrm{La}(37 \mathrm{mg} / \mathrm{kg}), \mathrm{Nd}(25 \mathrm{mg} / \mathrm{kg})$, and Y (36 mg/kg). The amount of the analyzed REEs was over $230 \mathrm{t}$
(Table 3). The distribution of these elements along the two cross sections (A-B and C-D) is shown in Figure 10. A high degree of similarity of most of the REEs (Dy, Er, Eu, Ho, Nd, Sc, Sm, Y and Yb) and their highest contents were found in the central and northern parts of the landfill (Figure 10). 

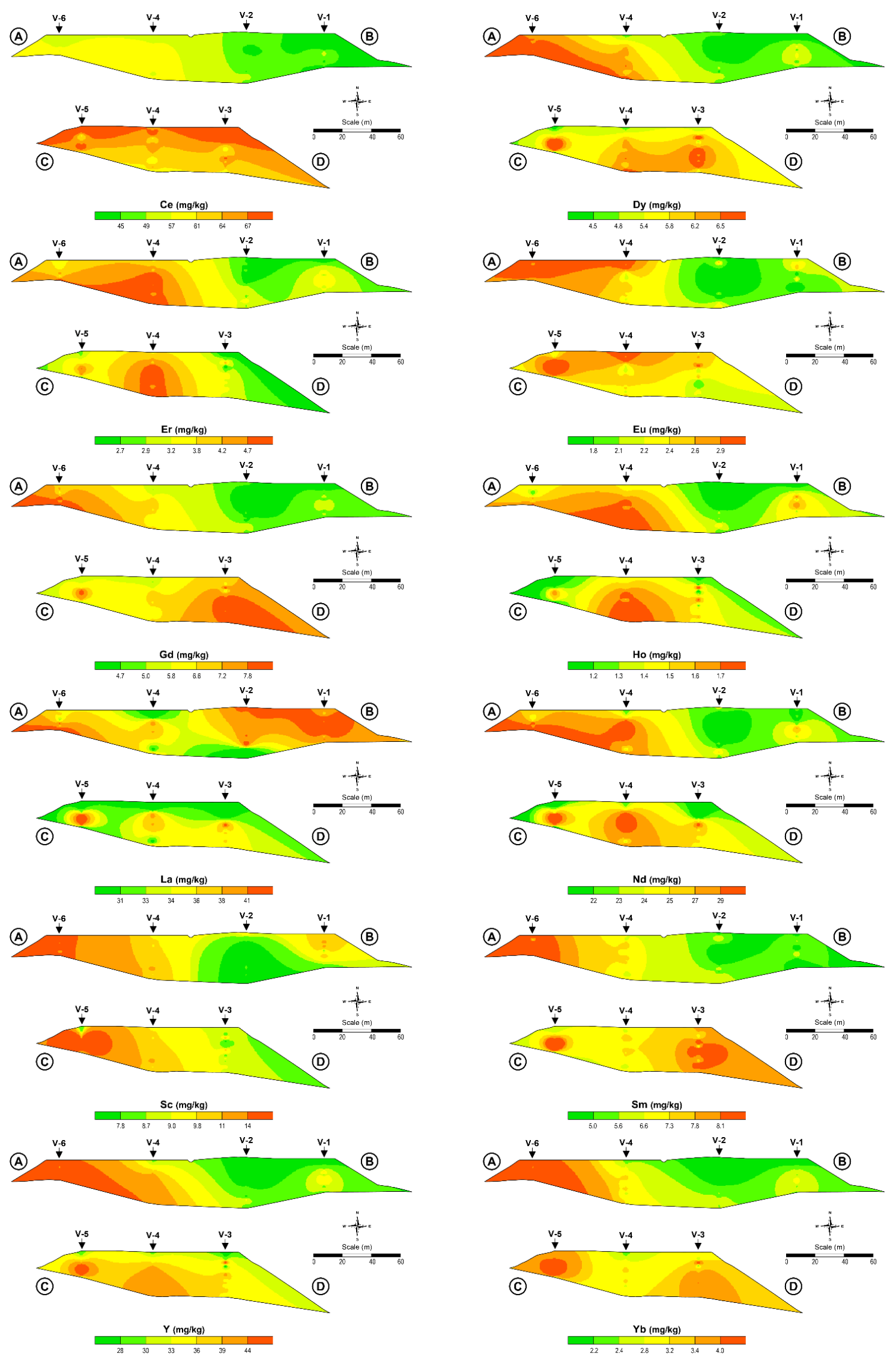

Fig. 10. Distribution of rare earth elements (Ce, Dy, Er, Eu, Gd, Ho, La, Nd, Sc, Sm, Y and Yb) in the Veles slag deposit (cross sections A-B and C-D); (see Fig. 5 for location of cross sections A-B and C-D) 


\section{CONCLUSION}

This study investigated the distribution of various chemical elements in the metallurgical slag deposit of the former Pb-Zn smelter "MHK Zletovo" in Veles, Republic of North Macedonia. For this purpose, sampling of waste material was carried out by drilling from top to bottom in 7 locations of the landfill and taking a sample every $2 \mathrm{~m}$ as one. Using ICP-MS 60 chemical elements were analyzed It was found that the composition of the slag in the landfill varies considerably. Besides $\mathrm{Pb}$ and $\mathrm{Zn}$, the most common metals of interest for further extraction are $\mathrm{Cd}, \mathrm{Ag}, \mathrm{Au}$ and In. However, the following metals are also present in economically significant quantities: As, Be, Bi, Cu, Fe, In, Mn, Nb, Pd, Sb, Se, Sn, $\mathrm{Te}$ and $\mathrm{Tl}$. It has been found that the average content of $\mathrm{Zn}$ is $9.6 \%$ (ranges from 5.6 to $14 \%$ ), and the total amount of amount $120,000 \mathrm{t}$, indicates a significant economic benefit in the recovery of the metals from this landfill. The presence of some rare earth elements $(\mathrm{Ce}, \mathrm{Dy}, \mathrm{Er}, \mathrm{Eu}, \mathrm{Gd}, \mathrm{Ho}, \mathrm{La}, \mathrm{Nd}, \mathrm{Sc}, \mathrm{Sm}, \mathrm{Y}$ and $\mathrm{Yb}$ ) is also significant.

Acknowledgment. The authors thank European Institute for Innovation and Technology for financial support RIS-RECOVER project No. 17128.

\section{REFERENCES}

Barandovski, L., Cekova, M., Frontasyeva, M. V., Pavlov, S. S., Stafilov, T., Steinnes, E., Urumov, V. (2008): Atmospheric deposition of trace element pollutants in Macedonia studied by the moss biomonitoring technique, Environmental Monitoring and Assessment, 138, 107-118.

Barandovski, L., Frontasyeva, M. V., Stafilov, R., Šajn, R., Pavlov, S., Enimiteva, V. (2012): Trends of atmospheric deposition of trace elements in Macedonia studied by the moss biomonitoring technique, Journal of Environmental Science and Health, Part A, 47 (13), 2000-2015.

Barandovski, L., Frontasyeva, M. V., Stafilov, T., Šajn, R., Ostrovnaya, T. (2015): Atmospheric deposition of trace elements in Macedonia studied by the moss biomonitoring technique, Environmental Science and Pollution Research, 22, 16077-16097.

Barandovski, L., Stafilov, T., Šajn, R., Frontasyeva, M. V., Bačeva, K. (2013): Air pollution study in Macedonia by using moss biomonitoring technique, ICP-AES and AAS, Macedonian Journal of Chemistry and Chemical Engineering, 32, 89-107.

Barandovski, L., Stafilov, T., Šajn, R., Frontasyeva, M., Bačeva Andonovska, K. (2020): Atmospheric heavy metal deposition in North Macedonia from 2002 to 2010 studied by the moss biomonitoring technique, Atmosphere, 11, 929 (2020), pp. 1-23.

Berdowski, J., Van der Most, P., Veldt, C., Bloos, J. P., Pacyna, J. M., Rentz, O., Oertel, D., Karl, U., Pulles, T., Appelman, W. (2009): EMEP/EEA Emission Inventory Guidebook, Zinc production - Manufacture of basic precious and nonferrous metals, European Environmental Agency, København, Denmark.

Bernas, B. (1968): A new method for decomposition and comprehensive analysis of silicates by atomic absorption spectrometry, Analytical Chemistry, 40, 1682-1686.

Bohlke, J., Friedrich, B., Hecker, E. (2005): Treatment of industrial lead and zinc slags in a pilot scale SAF, World of Metallurgy - Erzmetall, 58(4), 210-217.

EAR-MOEPP-Eptisa (2007): Feasibility Study - Volume II MHK Zletovo - Veles, Development of Remediation Plans with Financial Requirements for Elimination of Industrial Hotspots, EUROPEAID/123674/D/SER/MK, European Agency for Reconstruction, Ministry of Environment and Physical Planning of the Republic of Macedonia, EPTISA, Skopje.
Ettler, V., Johan, Z., Kř́ibek, B., Šebek, O., Mihaljevič, M. (2009): Mineralogy and environmental stability of slags from the Tsumeb smelter, Namibia, Applied Geochemistry, 24 (1), 1-15.

Ilić Popov, S., Stafilov, T., Šajn, R., Tánáselia, C., Bačeva, K. (2014): Applying of factor analyses for determination of trace elements distribution in water from river Vardar and its tributaries, Macedonia/Greece, The Scientific World Journal, 2014, 809253.

Ilić Popov, S., Stafilov, T., Šajn, R., Tánáselia, C. (2016): Distribution of trace elements in sediment and soil from river Vardar basin, Macedonia/Greece, Journal of Environmental Science and Health, Part A, 51, 1-14.

ISO 17294-2:2016 (2016): Water quality - Application of inductively coupled plasma mass spectrometry (ICP-MS)Part 2: Determination of selected elements including uranium isotopes. International Standard Organization, Geneva.

Jeftimova, M., Stafilov, T., Šajn, R., Bačeva Andonovska, K., Karadjova, I. (2016): Spatial distribution of chemical elements in soil samples in the Veles region, Republic of Macedonia, Geologica Macedonica, 30 (2), 103-114.

Jiang, K, Guo, Z., Xiao, X., Zhang, L. (2012): Extraction of metals from a zinc smelting slag using two-step procedure combining acid and ethylene diaminetetraacetic acid disodium, Journal of Central South University, 19, 1808-1812.

Kochubovski, M. (2009): Blood-lead levels in schoolchildren from Veles, related to the ambient air pollution by lead, exposure and risk assessment of chemical pollution - contemporary methodology. In: NATO Science for Peace and Security, Series C: Environmental Security. Springer, Heidelberg, pp. 371-378.

Langmyhr, F. J., Paus, P. E. (1968): The analysis of inorganic siliceous materials by atomic absorption spectrophotometry and the hydrofluoric acid decomposition technique, Part I, The analysis of silicate rocks, Analytica Chimica Acta, 43, 397-408.

Ma, A., Zheng, X., Li, S., Wang, Y., Zhu, S. (2018): Zinc recovery from metallurgical slag and dust by coordination leaching in $\mathrm{NH}_{3}-\mathrm{CH}_{3} \mathrm{COONH}_{4}-\mathrm{H}_{2} \mathrm{O}$ system, Royal Society Open Sciences, 5, 180660, 1-16.

Mladenovič, A., Mezga, K., Vrhovnik, P., Mauko Pranjić A., Šajn, R., Alijagić, J., Boev, B., Stafilov, T., Serafimovski, 
T., Lepitkova, S., Tasev, G., Boev, I., Ilijovski, Z., Filkovska, T., Schatzmann, W., Bergmans, L. (2018): Recycling of mining and metallurgical waste materials - Project Ris-Recover, Geologica Macedonica, 32(2), 173-175.

Morrison Knudsen Corporation (1992): Report for zinc slag pile remedial investigation at California Gulch Site Leadville, Colorado. Morrison Knudsen Corporation, December 11, 1992, Boise, Idaho.

Nikolovski, Z. (2008): Polluted Macedonian city to be rid of smelter, SE European Times, http://www.setimes.com/cocoon/setimes/xhtml/en_GB/features/setimes/features/200 8/05/01/feature-03

Pančevski, Z. (2015): Distribution of Heavy Metals in the Environmental Samples from Veles and its Environs, $\mathrm{PhD}$ thesis, Faculty of Natural Sciences and Mathematics, Ss. Cyril and Methodius University, Skopje.

Pančevski, Z., Stafilov, T., Frontasyeva, M. V. (2006): Copper in surface soil of Veles region, Macedonia, Geologica Macedonica, 20, 27-32.

Pančevski, Z., Stafilov, T., Bačeva, K. (2014a): Distribution of heavy metals in some vegetables grown in the vicinity of lead and zinc smelter plant, Contribution, Section of Natural, Mathematical and Biotechnical Sciences, Macedonian Academy of Sciences and Arts, 35, 25-36.

Pančevski, Z., Stafilov, T., Bačeva, K. (2014b): Distribution of heavy metals in lettuce and carrot produced in the vicinity of lead and zinc smelter plant, International Journal of Pure and Applied Chemistry, 9, 17-26.

Pančevski, Z., Stafilov, T., Bačeva, K. (2016): Distribution of heavy metals in the garden soil and vegetables grown in the vicinity of lead and zinc smelter plant, Journal of Scientific and Engineering Research,3, 94-104.

Pietrzyk, S., Palimąka, P., Stępień, M., Krawczykowska, A., Tora, B., Fatyga, M., Pajor, G., Mańka, A. (2017): Silver recovery from zinc metallurgical sludge - analysis of solutions, E3S Web of Conferences, 18, 01027, 1-6.

Reid, D., Galloway, J. M., MacDonald, J., Bach, B. B. (1970): Rapid analysis of slags and sinters by atomic absorption spectrometry, Metallurgia, 81 (488), 243-247.

Richards, G. G. (1983). Kinetics of the Zinc Slag Fuming Process, PhD thesis, The University of British Columbia, Vancouver, Canada.
Salminen, R., Batista, M. J., Bidovec, M., Demetriades, A., De Vivo, B., De Vos, W., Duris, M., Gilucis, A., Gregorauskiene, V., Halamic, J., Heitzmann, P., Jordan, G., Klaver, G., Klein, P., Lis, J., Locutura, J., Marsina, K., Mazreku, A., O'Connor, Olsson, S. Å., Ottesen, R. T., Petersell, V., Plant, J. A., Reeder, S., Salpeteur, I., Sandström, H., Siewers, U., Steenfelt, A., Tarvainen, T. (2005): Geochemical Atlas of Europe. Part 1, Background Information, Methodology and Maps, Geological Survey of Finland, Espoo.

Serafimovska, J. M., Arpadjan, S., Stafilov, T., Tsekova, K. (2013): Study of the antimony species distribution in industrially contaminated soils, Journal of Soils and Sediments, 13, 294-303.

Stafilov, T.. Šajn, R. (2016): Geochemical Atlas of the Republic of Macedonia, Faculty of Natural Sciences and Mathematics, Skopje, 2016.

Stafilov, T., Šajn, R. (2019): Environmental pollution of urban areas in the Republic of Macedonia due to the industrial activities, Science Conference „Pollution of the cities in the Republic of Macedonia: what are the solutions?", Proceedings, Macedonian Academy of Science and Arts, Skopje, pp. 153-156.

Stafilov, T., Šajn, R., Pančevski, Z., Boev, B., Frontasyeva, M. V., Strelkova, L. P. (2008): Geochemical Atlas of Veles and the Environs, Faculty of Natural Sciences and Mathematics, Skopje.

Stafilov, T., Šajn, R., Pančevski, Z., Boev, B., Frontasyeva, M. V., Strelkova, L. P. (2010): Heavy metal contamination of surface soils around a lead and zinc smelter in the Republic of Macedonia, Journal of Hazardous Materials, 175, 896914.

Stafilov, T., Šajn, R., Barandovski, L., Bačeva Andonovska, K., Malinovska, S. (2018): Moss biomonitoring air quality study of minor and trace elements in Macedonia, Air Quality, Atmosphere \& Health, 11 (2), 137-152.

Voigt, P. (2014): Recovery of Zinc from Lead Slag, Glencore Queensland Limited, Brisbane, Australia, World Intellectual Property Organization, International Bureau, International Application Number: PCT/AU20 13/000865.

\title{
Р е 3 и м е
}

\section{ГЕОХЕМИСКИ КАРАКТЕРИСТИКИ НА ОДЛАГАЛИШТЕТО НА ОЛОВНО-ЦИНКОВА ЗГУРА ОД МХК ЗЛЕТОВО ВО ВЕЛЕС, СЕВЕРНА МАКЕДОНИЈА}

\author{
Роберт Шајн ${ }^{1}$, Трајче Стафилов ${ }^{2}$, Блажо Боев ${ }^{3}$, Тодор Серафимовски ${ }^{3}$, Горан Тасев $^{3}$, Златко Илијоски ${ }^{4}$, Иван Боев $^{3}$ \\ ${ }^{1}$ Геолошки завоя на Словенија, Димичева 14, 1000 Љубљана, Словенија

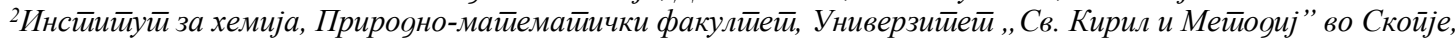 \\ Архимеgова 5, 1000 Скойје, Рейублика Северна Макеоонија

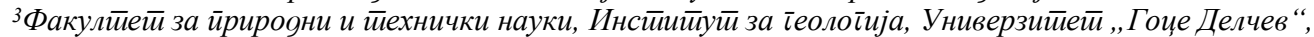 \\ 2000 Шӣий, Рейублика Северна Макеоонија \\ ${ }^{4}$ Граяежен инстиитиуй „Макеgонија“, Дрезяенска 52, 1000 Скойје, Рейублика Северна Макеgонија \\ Robert.Sajn@geo-zs.si
}

Клучни зборови: RIS-RECOVER; Pb-Zn згура; МХК Злетово; Велес; Северна Македонија

Проектот „Регионална иновативна шема за екстракција на критични минерални суровини со нула отпад“ (RISRECOVER), е имплементиран во рамките на Европскиот институт за иновации и технологии (ЕIT) за да се оцени и одбере најветувачка технологија за минералошка и металуршка екстракција на елементи од металуршки отпад во 
Република Северна Македонија. Овој проект е фокусиран на металуршката згура од поранешната топилница за олово и цинк „МХК Злетово“, која е одлагана во непосредна близина на Велес. Примероците на отпаден материјал се добиени со дупчење низ лежиштето на згурата на осум локации и се емани на секои $2 \mathrm{~m}$. Со користење на индуктивно спрегната плазма - масена спектрометрија (ICP-MS) беа анализирани 60 хемиски елементи. Констатирано е дека лежиштето на згурата е хетерогено. Најчести елементи интересни за понатамошна екстракција беа $\mathrm{Zn}$ и $\mathrm{Pb}$, следени од $\mathrm{Cd}, \mathrm{Ag}$, $\mathrm{Au}$ и In; но во економски количества беа присутни и следните метали: $\mathrm{As}, \mathrm{Be}, \mathrm{Bi}, \mathrm{Cu}, \mathrm{Fe}, \mathrm{Mn}, \mathrm{Nb}, \mathrm{Pd}, \mathrm{Sb}, \mathrm{Se}, \mathrm{Sn}, \mathrm{Te}$ и $\mathrm{Tl}$, заедно со елементите на ретки земји. Средната содржина на $\mathrm{Zn}$ беше $9.6 \%$ (од 5.6 до 14\%), а вкупното количество од околу 120.000 t укажува на можна економска добивка од екстракција на металите од ова јаловиште. 